\title{
Canadian Journal of Plant Science
} Revue canadienne de phytotechnie

\section{Effect of green manure crops, termination method, stubble crops and fallow on soil water, available $\mathbf{N}$ and exchangeable $\mathbf{P}$.}

\begin{tabular}{|r|l|}
\hline Journal: & Canadian Journal of Plant Science \\
\hline Manuscript ID & CJPS-2015-0336.R1 \\
\hline Manuscript Type: & Article \\
\hline Complete List of Authors: & $\begin{array}{l}\text { Mooleki, Patrick; Saskatchewan Ministry of Agriculture, Agriculture } \\
\text { Knowledge Centre } \\
\text { Gan, Y.; Agriculture and Agri-Food Canada, } \\
\text { Lemke, Reynald; Agriculture \& Agri-Food Canada, Research Branch } \\
\text { Zentner, Robert } \\
\text { Hamel, Chantal; AAFC, SCRDC }\end{array}$ \\
\hline Keywords: & Agronomy, Cover crop, Legume, Nitrogen, Water \\
\hline &
\end{tabular}

SCHOLARONE

Manuscripts 


\title{
Effect of green manure crops, termination method, stubble crops and fallow on soil water, available $\mathrm{N}$ and exchangeable $P$.
}

S. P. Mooleki ${ }^{1}$, Y. Gan ${ }^{2,}$, R. L. Lemke ${ }^{3}$, R. P. Zentner ${ }^{2}$ and C. Hamel $^{4}$

${ }^{1}$ Agriculture Knowledge Centre, Regional Services Branch, Saskatchewan Ministry of Agriculture, Moose Jaw, SK, S6J 1L8;

${ }^{2}$ Agriculture and Agri-Food Canada, Swift Current Research and Development Centre, Swift Current, SK, S9H 3X2;

${ }^{3}$ Agriculture and Agri-Food Canada, Saskatoon Research Centre, 107 Science Place, Saskatoon, SK, S7N 0X2.

${ }^{4}$ Agriculture and Agri-Food Canada, Quebec Research and Development Centre, Hochelaga, Québec, G1V 2J3.

*Corresponding author (email: yantai.gan@agr.gc.ca)

\begin{abstract}
Mooleki, S.P., Gan, Y., Lemke, R.L., Zentner, R.P. and Hamel, C. Effect of green manure crops, termination method, stubble crops and summerfallow on soil water, available $\mathrm{N}$ and exchangeable P. Can. J. Plant Sci. 96: xxx-xxx. Green manure crops may have a role to play in the development of sustainable agricultural systems in the semiarid northern Great Plains of North America. This study determined the benefits of different green manure crops, seeding dates, and termination methods on soil nitrogen, phosphorus and moisture, as well as the performance of durum wheat following green manures the following year. Field experiments were conducted at Swift Current, Saskatchewan, 2006-2009. Three green manure crops [forage pea (Pisum sativum L.), chickling vetch (Lathyrus sativus L.) and black lentil (Lens culinaris Medik.)] were seeded in May, June and July and terminated at full bloom using glyphosate, rototilling or by frost. Other treatments included summerfallow and stubble of selected crops
\end{abstract}


harvested for grain or silage. Different green manure crops, seeding dates or termination methods had similar effects on soil moisture, available $\mathrm{N}$ and exchangeable $\mathrm{P}$ at termination or the following spring. These effects of green manure management on soil residual characteristics were comparable to those observed under summerfallow, but higher than those on grain or silage stubble. Therefore, green manure is a viable alternative to summerfallowing and could be seeded any time during the growing season. If seeded late, green manure could be terminated by frost, thus saving on costs.

Key words: Green manure, green manure termination, available soil nitrogen, soil water conservation, exchangeable phosphorus, semi-arid environments.

In the semiarid northern Great Plains, soil moisture is the most important factor limiting crop production, followed by soil nitrogen $(\mathrm{N})$ and phosphorus $(\mathrm{P})$. Production of cereal crops followed by summerfallow was the traditional cropping system in the region. During the summerfallow period soil moisture is conserved (Tanaka and Aase 1987) and organic matter breakdown and nutrient mineralization is enhanced, thereby increasing the productivity of subsequent cereal crops (Campbell et al. 2008; Hunt et al. 2013). However, due to detrimental effects of cereal-fallow system, such as decreased soil quality and increased soil erosion risks (Lemke et al. 2012; Panettieri et al. 2014), the practice of conventional summerfallow has declined. Instead, more diversified cropping systems have been widely adopted, where broadleaf crops such as oilseeds and pulses are arranged in longer crop rotation cycles with cereals, allowing the reduction or elimination of summerfallow and the increased use of soil residual nutrients and water (Gan et al. 2016). 
Green manuring has been found to be an environmentally friendly alternative to summerfallowing. However, growing a green manure crop may deplete soil moisture that is needed for the subsequent crop (Biederbeck et al, 1994; Zentner et al. 1996). Therefore, shortseason pulse crops such as field pea and lentil are grown, offering a 'partial fallow' effect (Curtin et al. 2000). The use of leguminous crops as green manure has additional benefits in that the legume crop adds nitrogen $(\mathrm{N})$ to the soil through symbiotic $\mathrm{N}$ fixation. This decreases the use of inorganic N fertilizer (Kirkegaard and Ryan 2014) and increase system productivity (Gan et al. 2015); these help reduce the carbon footprint of crop production (Gan et al. 2014), improve farm sustainability (Zentner et al. 2011; Roper et al. 2012) and enhance profitability (Zentner et al. 2004).

However, little research has been reported in fine-tuning the management methods for annual legume green manure crops. Legume type, dates of seeding and termination, and method of termination of the green manure crop may influence $\mathrm{N}$ fixation, biomass yield, and $\mathrm{N}$ content of the plants. Seeding and termination date can directly impact soil water conservation which is critical for the subsequent crops, and can influence the rate and timing of $\mathrm{N}$ released from the green manure residue, thereby influencing the risk of $\mathrm{N}$ loss via leaching and denitrification. Hence, the objectives of this study were to determine the effect of type of green manure, seeding and termination date and method of termination on green manure water use and conservation, $\mathrm{N}$ and $\mathrm{P}$ benefits, and crop performance of a subsequent durum wheat crop. These green manure effects were compared to those observed on stubble of harvested spring wheat, field pea, and forage pea, and on conventional fallow. Detailed performance of durum wheat following green manure, summerfallow and the other pulse crops is reported elsewhere (Gan et al. 2016), and the present paper only discusses the performance of the different green manure crops and the effect 
of the growing period and termination method on soil water, available $\mathrm{N}$ and exchangeable phosphorus (P).

\section{MATERIALS AND METHODS}

\section{Field Experimentation}

This study was conducted at the Agriculture and Agri-Food Canada Research Centre, Swift Current, Saskatchewan $\left(50^{\circ} 25^{\prime} \mathrm{N}, 107^{\circ} 44^{\prime} \mathrm{W}\right)$. The soil is an Orthic Brown Chernozem with a silt loam texture containing $28 \%$ sand, $49 \%$ silt, and $23 \%$ clay, and with an organic C content of 20 $\mathrm{g} \mathrm{kg}^{-1}$ and $\mathrm{pH}\left(\mathrm{CaCl}_{2}\right)$ of 6.5 in the top $15 \mathrm{~cm}$ depth at the beginning of the experiment (in 2006). Soil nutrients were measured prior to seeding each year by taking 24 soil samples ( 6 per replicate) from the plot area. In 2006, soil contained $24-23-450-25 \mathrm{~kg} \mathrm{ha}^{-1}$ of N-P-K-S; in 2007 , they were 20-25-452-50; and in 2008, they were 26-23-388-34. The $\mathrm{N}$ included $\mathrm{NO}_{3}$ and $\mathrm{NH}_{4}$.

Sixteen treatments (Table 1) were arranged in a randomized complete block design (RCBD) with four replicates. In the establishment year, plot dimensions were $5 \times 10 \mathrm{~m}$ with a $0.3 \mathrm{~m}$ boundary between each plot. Three green manure crop types used were forage pea (Pisum sativum L. var. CDC Sonata) seeded at $246 \mathrm{~kg} \mathrm{ha}^{-1}$, targeting 80 plants $\mathrm{m}^{-2}$; chickling vetch (Lathyrus sativus L. var. AC Greenfix) seeded at $146 \mathrm{~kg} \mathrm{ha}^{-1}$, targeting 60 plants $\mathrm{m}^{-2}$; and black lentil (Lens culinaris L. var. Indianhead) seeded at $56 \mathrm{~kg} \mathrm{ha}^{-1}$, targeting 120 plants $\mathrm{m}^{-2}$. The three harvested crops included forage pea (same as above) cut for silage; yellow pea (Pisum sativum L. var. CDC Eclipse) seeded at $213 \mathrm{~kg} \mathrm{ha}^{-1}$, targeting 80 plants $\mathrm{m}^{-2}$; and spring wheat (Triticum aestivum L. var. Lillian) seeded at $99 \mathrm{~kg} \mathrm{ha}^{-1}$, targeting 150 plants $\mathrm{m}^{-2}$. The $16^{\text {th }}$ treatment was a summerfallow. Green manures, forage pea and yellow pea were inoculated with peat-based 
Rhizobium inoculants (Nitragin GC ${ }^{\circledR}$, Novozymes, Saskatoon, SK Canada) at the rate of $100 \mathrm{~g}$ inoculant per $25 \mathrm{~kg}$ of seed; and were seeded at three seeding-termination dates designated 'Early', 'Mid' and 'Late' (Table 1).

A pre-seeding burn-off treatment with $180 \mathrm{~g}$ a.e. $\mathrm{ha}^{-1}$ of glyphosate [N-(phosphonomethyl) glycine] was applied to all plots to control weeds. No fertilizer was applied to legume crops. Spring wheat received $68 \mathrm{~kg} \mathrm{~N} \mathrm{ha}^{-1}$ and $23 \mathrm{~kg} \mathrm{P}_{2} \mathrm{O}_{5} \mathrm{ha}^{-1}$ based on general recommendations for the area. Summerfallow check plots were managed using commonly-adopted summerfallowing practices (Campbell et al. 2007; Zentner et al. 2011). During summerfallow, weeds were controlled by two to three tillage operations with a cultivator and an additional tillage with a rod weeder when needed. Early and mid green manure crops were terminated by applying glyphosate at the rate of $540 \mathrm{~g}$ a.e. $\mathrm{ha}^{-1}$. Late green manure crops were left to natural frost-kill which occurred on September 19 in 2006, on September 20 in 2007, and on October 9 in 2008. Treatments terminated by incorporation were terminated using a rototiller on or about the same date as early green manure crops terminated by glyphosate. Forage pea harvested for silage was swathed at the same time as early green manure was terminated and picked up for silage soon after.

Plant density was measured on 1-m row lengths from two positions in each plot 2 weeks after initial seedling emergence. Aboveground plant biomass was determined at the time of crop termination on all plots by collecting biomass from three half-meter row lengths by hand from two positions in each plot. The samples were bulked, dried at $60{ }^{\circ} \mathrm{C}$, and weighed when the samples reached a constant weight after 2 to 4 days. Seed yield of yellow pea and spring wheat was determined at full maturity by harvesting the central six rows in each plot using a plot combine harvester. Moisture content of the seed samples was determined and the mass of all 
samples was normalized to a standard moisture content of $14.5 \%$. Seed and straw samples were ground and analyzed for $\mathrm{C}, \mathrm{N}$ and $\mathrm{P}$ content. The $\mathrm{N}$ concentrations in the seed and straw were determined using the standard micro-Kjeldahl method. Carbon concentration of the plant samples was analyzed with an automated combustion technique (Carlo Erba $^{\mathrm{TM}}$, Milan, Italy).

Total N (\%) was multiplied by 5.7 to calculate protein content (\%) in seed (Williams et al. 1998). Nitrogen and $\mathrm{P}$ uptake in seed and straw were determined individually by multiplying plant dry weight by $\mathrm{N}$ and $\mathrm{P}$ concentrations, respectively.

Soil samples were taken using a hydraulic punch probe to a depth of $120 \mathrm{~cm}$, within three days after termination. Each soil core was sub-divided into five segments of: 0-15, 15-30, 30-60, 6090 and 90-120 cm, respectively. Two cores were taken from random positions in each plot and the segments for each soil depth thoroughly mixed. The soil samples were air dried, ground to pass through 2-mm sieve, extracted using $2 \mathrm{M} \mathrm{KCl} \mathrm{(10:1} \mathrm{solution} \mathrm{to} \mathrm{soil} \mathrm{ratio),} \mathrm{and} \mathrm{filtered}$ (Keeney and Nelson 1982) for the determination of inorganic $\mathrm{N}\left(\mathrm{NO}_{3}-\mathrm{N}\right.$ and $\left.\mathrm{NH}_{4}-\mathrm{N}\right)$ using automated colorimetry (Autoanalyzer II, Technicon Industrial Systems 1978).

\section{Statistical Analysis}

A preliminary analysis of variance with Mixed model indicated that treatment had a significant effect and interacted with year to influence crop response and soil variables. Ordinarily, year is considered as a random factor and any treatment by year interaction is considered to be random. In this study, treatment and year were considered as fixed factors. Littell et al (2006) and Fernandez (2007) indicate that if the number of observations for a factor ordinarily considered random is not large enough to give a sizable representation of such a population of observations, the factor should be considered to have a fixed effect. Whereas this may limit its inferential 
scope, it facilitates discussing the observed effects. Significant mean differences were separated using Tukey’s Honestly Significant difference (HSD) at $\alpha<0.05$ level of significant.

\section{RESULTS AND DISCUSSION}

\section{Weather Conditions}

Meteorological information was obtained from a station located within $8 \mathrm{~km}$ from the site, except for 2007 September, which was obtained as a mean from two Environment Canada weather stations near Swift Current. This information is provided in Fig. 1 A. In all three years, precipitation in April and May were similar and slightly below the 30-year normal precipitation for those months. Major differences were observed in subsequent months, particularly in June. In 2006, June precipitation was above normal by about $40 \%$ while in 2008 , June precipitation was almost double the expected precipitation. In contrast, June precipitation in 2007 was near but below normal. Far below normal precipitation was observed in July and August of 2006 and 2007, while in 2008, precipitation in July and August was well above normal. In 2006, precipitation in September was more than double the normal amount while in 2007 and 2008, September precipitation was just below normal. Thus, the amount of precipitation received by the crop prior to termination was highest in 2008 and lowest in 2007 (Fig. 1 B). Post-termination precipitation was higher and similar for 2006 and 2008 than in 2007.

\section{Yield and other characteristics of green manure and harvested crops}

Green manure (GM) crops, forage pea (FP), chickling vetch (CV) and black lentil (BL) were seeded at three different dates and allowed to grow to full bloom of CV before termination (Table 1). These three dates are designated Early (E), Mid (M) and Late (L) seeding and represent green manure timing. Yellow pea (YP) and spring wheat (SW) harvested for grain and 
FP cut for silage (Slg) were seeded on the first seeding date for each year. The effective duration in weeks from seeding to termination or harvesting are indicated in Table 1. To look at the effects of crop type, time of seeding and year, 12 treatments (from Table 1) were selected, namely: $1,2,3,7,8,9,10,11,12,13,14$ and 15 and included in the analysis. Treatment 4,5 and 6 were omitted as they represented early-seeded incorporated GM treatments. However, incorporated GM treatments were not represented in mid and late-seeded treatments. The fallow treatment (16) was also excluded as there was no crop grown on it.

Aboveground biomass yield varied with GM type, timing and year. Significant year by treatment interaction effects were observed on nearly all crop parameters. Hence, the characteristics of the GM and harvested crops for all the three years $(2006,2007$ and 2008) as well as the average are presented (Fig. 2). Aboveground biomass yield for early seeded FP was significantly higher than that of CV and BL in 2006 and 2008, and when averaged over the three years. As a whole, aboveground GM biomass yield was lowest in 2007, a year which was drier than normal. Above normal precipitation in September of 2006 helped the late seeded GM crops yield higher than mid-seeded counterparts, although BL was found not significantly higher. In contrast, despite higher precipitation in June, July and August of 2008, the late seeded GM crops yielded the lowest compared to early and mid-seeding periods. It is likely that above normal precipitation may have created conditions too wet for the establishment and development of the late-seeded legume GM crops. Pulse crops (peas and lentils, in particular) do not like "wet feet".

Averaged over the three years, aboveground biomass yield of all three GM crops were similar regardless of the timing, with two exceptions. Early-seeded FP significantly out-yielded any other treatment. Late-seeded BL resulted in a significantly lower aboveground biomass yield than any other treatment, except late-seeded CV. 
Aboveground biomass yields of harvested crops were all higher than those of GM crops in all three years. The only exception was in 2008 when FP cut for silage yields were similar to those of all mid-seeded GM crops and early-seeded FP. Aboveground biomass yield of harvested spring wheat was significantly the highest in all three years, as well as on average.

Total $\mathrm{N}$ in aboveground biomass followed a similar trend as aboveground biomass yield with the exception of harvested YP and SW. Averaged over the three years, forage pea cut for silage and GM FP exhibited significantly higher total $\mathrm{N}$ in aboveground biomass than any other treatment. Among GM treatments, late-seeded BL exhibited the lowest total $\mathrm{N}$ in aboveground biomass, likely as a result of the poor aboveground biomass yield in the driest and wettest years (2007 and 2008, respectively) in the study. Total $\mathrm{N}$ in aboveground biomass of harvested YP was similar to those of the mid and late-seeded GM crops, but significantly higher than that of harvested SW, which exhibited the lowest total $\mathrm{N}$ in aboveground biomass among all treatments.

Total $\mathrm{P}$ in aboveground biomass followed a similar trend as total $\mathrm{N}$ in aboveground biomass, but amounts were about ten-fold less (Fig. 2). Total P in aboveground biomass was highest in FP cut for silage and in green manure FP. Total P in aboveground biomass was lowest in harvested YP and SW, although not significantly different from late-seeded green manure. Trend in total carbon in aboveground biomass was similar to that of aboveground biomass yield. The harvested crops exhibited the highest amount of total carbon in aboveground biomass.

On average, the aboveground biomass yields observed in this study fall in the range reported by Biederbeck et al. (1993) of 601 to $3961 \mathrm{~kg} \mathrm{ha}^{-1}$, the exception being late-seeded BL in the dry year. Chickling vetch seemed to grow well at all seeding dates and would likely be the best choice if one had to seed late. This may be due to its early-development capability (Biederbeck 
et al. 1993) which allows it to accumulate sufficient aboveground biomass early on. In contrast, FP seemed to perform best when seeded early. Hence, among the three GM crops, FP would be the GM of choice if one is able to seed early.

\section{Effect on soil water and water use}

To assess the effect of green manuring on soil moisture and water use by the crop, soil moisture status was measured at the time of termination, late fall and in the spring of the following season at the following soil profile segments: $0-15 \mathrm{~cm}, 15-30 \mathrm{~cm}, 30-60 \mathrm{~cm}, 60-90 \mathrm{~cm}$ and $90-120 \mathrm{~cm}$. As well, changes in soil water status between termination and late fall, between late fall and spring of the following year, and between termination and spring of the following year were determined. The same treatments used in assessing aboveground biomass characteristics were used. In addition, the fallow treatment was included, bringing the total number of treatments in the analysis to 13 .

Year by treatment interaction effects were observed for some of the variables at certain soil profile depths (Table 2). Analysis of these interaction effects showed that while the trend was similar in all the three years, some treatments were significantly lower or higher than others in some years, resulting in significant interaction effects. Thus, average treatment results are presented and discussed and where significant year by treatment effects were observed, they are highlighted and discussed as well.

The difference in measured soil water between seeding and termination, taking into account precipitation during that period is referred to as water use (Biederbeck and Bouman, 1994). Averaged over the three years, spring wheat (SW) used more water from the top $15 \mathrm{~cm}$ of the soil profile at termination than all other crops but not different from other harvested crops (Fig. 
3). Early and mid-seeded GM crops used similar amounts of water which was significantly higher than that used by late season crops in the top $15 \mathrm{~cm}$ of the soil. The fallow maintained the same amount of water in the top $15 \mathrm{~cm}$ of the soil between early seeding and GM termination. In the $15-30 \mathrm{~cm}$ soil profile, early seeded GM crops used a similar amount of water as late seeded crops while mid-seeded GM crops used a similar amount of water as harvested crops, which was higher than that used by early and late-seeded GM crops. Early seeded GM crops used soil water in the top $30 \mathrm{~cm}$ of the soil and tended to accumulate moisture in the $30-60 \mathrm{~cm}$ soil profile. On the other hand, mid and late-seeded GM crops used the lowest amount in the top $15 \mathrm{~cm}$ of the soil, and increasingly used more moisture in the $15-30$ and $30-60 \mathrm{~cm}$ soil profiles. While earlyseeded GM accumulated soil water in the $30-60 \mathrm{~cm}$ soil profile and below, mid and late-seeded GM crops did not, but used some moisture even in the $60-120 \mathrm{~cm}$ soil profile.

Looking at the individual years, in a year with sufficient precipitation early-seeded GM crops use water mainly from the top $30 \mathrm{~cm}$ of the soil profile, and are likely able to allow the lower soil profile to be recharged. In a drier year (e.g. 2007), early-seeded GM crops extract soil water all the way down to $60 \mathrm{~cm}$ soil profile and allow minimal recharge in the lower segments during the season. This was similar to harvested crops. Spring wheat in particular, used more soil water in the $30-60 \mathrm{~cm}$ profile than in the upper soil layer segments. Late-seeded and to some extent midseeded GM crops used more soil water in the $30-60 \mathrm{~cm}$ profile than the upper segments regardless of whether precipitation was above or below normal. Overall, summerfallow conserved more soil water below the $30 \mathrm{~cm}$ soil profile than any other treatment, particularly in the wet year of 2008 .

At termination, soil water was highest in the summerfallow; followed by late-seeded GM crops at all soil profile depths (Fig. 3). Spring wheat exhibited the lowest soil water levels at 
termination followed by FP cut for silage and harvested YP in that order. Similar soil water levels were observed in the early and mid-seeded GM crops in the top $60 \mathrm{~cm}$ soil profile.

Overall, similar trends in soil water levels among the treatments were observed in late fall and the following spring. At all these times, summerfallow and late-seeded GM crops exhibited highest soil water levels while harvested crops, in particular SW, exhibited the lowest soil water levels.

No differences in soil water were observed among GM crops, although it was noted that soil water levels in BL in 2007 were similar to those in summerfallow in the $0-60 \mathrm{~cm}$ soil profile. This is attributed to the near failure in BL crop as shown in aboveground biomass yield (Fig. 2) as a result of low precipitation. Interesting as well, is the fact that despite the large amount of water use in the $30-60 \mathrm{~cm}$ soil water profile by late-seeded GM crops, soil water levels at this profile was similar to that in summerfallow and higher than that in early-seeded GM, at all three sampling periods.

A closer look at the changes in soil water between termination and late fall, late fall and spring, and termination and spring shows significant differences among treatments (Fig. 4). Averaged over the three years, plots with stubble of harvested crops gained more soil water in the top 30 $\mathrm{cm}$ of the soil between harvest and late fall. In the $30-60 \mathrm{~cm}$ profile, harvested crops gained some moisture but not significantly different from GM crops. Harvested SW and YP resulted in decreased soil water below the $60 \mathrm{~cm}$ soil profile. Cutforth et al. (2013) found that compared to spring wheat, pulse crops withdrew less water from the soil, and even less so below $80 \mathrm{~cm}$. This is likely because more than $90 \%$ of pulse crop root volume is found in the top $60 \mathrm{~cm}$ of the soil (Gan et al. 2011). Soil water content on summerfallow and late-seeded GM crops declined between termination and fall at all soil profile levels. On the other hand, early-seeded GM 
resulted in a significant increase in soil water between termination and late fall in the top $30 \mathrm{~cm}$ of the soil.

In 2006, with the exception of early seeded BL, early-seeded GM and harvested crops gained significant soil moisture between termination and late fall in the top $30 \mathrm{~cm}$ of the soil compared to summerfallow. The decline in soil moisture in the summerfallow was also significant in the 30-60 cm soil profile. This indicates that summerfallow can lose significant amounts of soil moisture in the fall prior to freeze up, despite the late above normal precipitation. This is attributed to higher evaporative losses from the bare soil (Tanaka and Aase 1987; De Jong et al. 2008). On the other hand, early to mid-seeded GM crops can provide sufficient soil cover to retain moisture from late season precipitation. No differences in soil water changes between termination and late fall were observed in 2007, a year with below normal precipitation.

No significant differences in changes in soil water were observed among all treatments at all levels between late fall and spring. However, on average, soil moisture changes were positive for all treatments over the winter. The overall results showed significant soil water changes between termination and spring. The differences were significant in the 0-30 $\mathrm{cm}$ soil profile. Changes were not significant in the $30-60 \mathrm{~cm}$ soil profile and below. Overall, on summerfallow, soil moisture in the $0-30 \mathrm{~cm}$ soil profile slightly declined while soil moisture on GM treatments and harvested stubble increased between termination and spring. Among GM crops, earlyseeded treatments resulted in the highest increases in soil moisture between termination and spring, followed by mid-seeded GM and late-seeded GM, in that order.

In this study averaged over the three years, GM regardless of time of seeding did not significantly reduce soil water relative to summerfallow at all soil levels measured. This may be 
attributed to early termination of the GM before substantial soil moisture is used up by the GM. Brandt (1996) noted that during most years, soil water use by an early-incorporated GM crop was similar to surface evaporation losses on summerfallow. In addition, summerfallow usually gained less water than cropped treatments and occasionally showed net loss of soil water overwinter. Similar observations were made in this study. Soil water declined in the top $30 \mathrm{~cm}$ between termination and late fall on summerfallow but barely changed overwinter resulting in a slight moisture reduction between termination and spring. The failure by summerfallow to accumulate moisture overwinter is attributed to snow blow off due to lack of sufficient snow trapping stubble and crop residue on the soil surface, and to the freezing of the wet and bare soil surface that may restrict water infiltration during snowmelt or spring thaw events (De Jong et al. 2008). On the other hand, soil moisture on GM increased between termination and fall, resulting in a significant increase in soil water between termination and spring. The ability of GM to recharge between termination and spring combined with low water use of an early terminated GM resulted in spring soil moisture levels on GM which were comparable to those on summerfallow. Our results are similar to those of Brandt (1996) at Scott, SK, in the Dark Brown Soil zone, where spring soil water on summerfallow was not different from that on GM treatments. Pikul et al. (1997) also found no difference in spring soil moisture between GM and fallow treatments.

\section{Effect on available nitrogen and phosphorus}

Averaged over the three years, at termination, available $\mathrm{N}$ was highest in summerfallow than in early and mid-seeded GM crops or harvested crops in the top $30 \mathrm{~cm}$ of the soil (Fig. 5). No differences were observed in lower soil profiles, except harvested SW and FP cut for silage which exhibited lower levels of available $\mathrm{N}$ in the $90-120 \mathrm{~cm}$ soil segment. Late-seeded GM 
crops exhibited higher levels of available $\mathrm{N}$ at termination than early-seeded GM crops.

However, the opposite was the case by late fall. Overall, no differences among GM treatments were observed by the following spring in any of the soil segments.

Differences were observed among the three years of study. In the drier season of 2007, lateseeded GM crops exhibited significantly higher levels of available $\mathrm{N}$ in the $0-15 \mathrm{~cm}$ soil segment compared to early-seeded GM crops at termination. Mid-seeded GM crops were intermediate and similar to summerfallow in terms of available $\mathrm{N}$ at termination in the top $30 \mathrm{~cm}$ soil segment. In the moister seasons (2006 and 2008), no differences in available N were observed among GM treatments in the top $30 \mathrm{~cm}$ soil segment at termination. Due to poor growth of BL in 2007, available $\mathrm{N}$ in the top $30 \mathrm{~cm}$ of the soil was similar to that in summerfallow, and different from other GM treatments. High amounts of available N were observed at termination in the lower soil segments $(30-120 \mathrm{~cm})$. However, due to large variations within treatments, significant differences were barely detected, particularly below $60 \mathrm{~cm}$ soil depth.

Levels of available $\mathrm{N}$ increased between termination and spring in the top $60 \mathrm{~cm}$ of the soil profile (Fig. 6). Significant increases in available N were observed in early-seeded GM crops and crops harvested for grain or FP cut for silage in comparison to late-seeded GM crops in the 0-15 cm soil profile. The bulk of these changes occurred between termination and late fall, with minimal changes in available $\mathrm{N}$ between late fall and spring. Substantial decline in available $\mathrm{N}$ was observed in summerfallow between late fall and spring in the $60-120 \mathrm{~cm}$ soil segment. This decline was not significant compared to changes in other treatments.

Although differences in changes were not significant at the chosen level of significance, it's worth noting that in a year with near normal precipitation like 2006, sizable mineralization takes 
place between termination and late fall resulting in increases in available $\mathrm{N}$ at all soil depths. However, in a wet year like 2008, increases in available $\mathrm{N}$ may occur in the top $60 \mathrm{~cm}$ of the soil profile, but substantial loses may also occur in the lower segments. Available $\mathrm{N}$ in summerfallow decreased substantially both between termination and late fall and between late fall and spring. Substantial decreases in available N in FP cut for silage below $30 \mathrm{~cm}$ occurred mainly between termination and late fall in 2008. Overall, although available $\mathrm{N}$ was higher at termination in late-seeded GM crops (Fig. 5), the differences diminished by spring of the following year, resulting in no difference in available N among GM treatments at all soil depth segments.

Significant differences in exchangeable $\mathrm{P}$ in 0-15 cm at termination were only observed in 2006 (Fig. 7) between early-seeded CV and BL at all seeding dates. Averaged over the three years, no differences were observed at termination among all treatments at all soil depths, with the exception of summerfallow which had higher exchangeable $\mathrm{P}$ in the $30-60 \mathrm{~cm}$ soil profile than harvested SW. In 2007, early-seeded CV exhibited higher exchangeable P in late fall in the 0-15 $\mathrm{cm}$ soil profile than mid-season $\mathrm{CV}$. This difference was also observed when averaged over the three years. As well, in late fall, exchangeable $\mathrm{P}$ was higher in the $30-60 \mathrm{~cm}$ profile in summerfallow than in harvested SW. However, none of these differences were observed by spring time. The only difference in exchangeable $\mathrm{P}$ in spring was observed in the $30-60 \mathrm{~cm}$ profile where summerfallow plots exhibited higher exchangeable P than in FP cut for silage. Hence, by and large, none of these treatments affected levels of exchangeable $\mathrm{P}$, even in the top $15 \mathrm{~cm}$ of the soil where you would normally expect to see effects on P availability.

\section{Effect of green manure termination method}


Two methods were used to terminate green manure at full bloom, namely by glyphosate application and by incorporation with a tandem disc harrow. Termination by incorporation was only applied to early-seeded GM crops. Hence, this assessment looks at termination methods for early-seeded GM crops. Harvested crops and summerfallow treatments were included in the analysis in order to provide complete assessment and comparison. Thus, ten treatments were included in the analysis, namely, Treatments $1,2,3,4,5,6,13,14,15$ and 16 (Table 1 ). The results of this analysis are provided in Table 3.

Significant year by treatment effects were observed at certain soil depth segments at termination, late fall and in the spring. The nature of the interaction effects at these soil depths are presented in Fig. 8. By and large, the GM treatment effects across the three years were similar, but differed only in magnitude from one year to another. It appears that much of the year by treatment interaction effect was attributed to summerfallow effects which differed from those caused by GM treatments from one year to another. Hence, results are presented on an average basis across the three years.

Averaged over the three years, no differences in soil moisture at termination, late fall or spring were observed between glyphosate and incorporation terminated GM crops (Fig. 9). Both methods of GM termination resulted in soil water content that was intermediate between summerfallow and harvested crops. These differences were significant at termination at all soil depths down to $120 \mathrm{~cm}$. However, in late fall, differences were observed in the $15-90 \mathrm{~cm}$ soil segments, where harvested SW exhibited lower soil water than most of the incorporated GM treatments. By spring time, soil water in GM treatments terminated by either glyphosate or incorporation was not significantly different from that observed on summerfallow at all soil sampling segments. No differences in changes in soil water were observed between GM crops 
terminated by glyphosate or those terminated by incorporation for any soil sampling segment, whether at termination, late fall or in the spring (Fig. 8).

Significant year by treatment interaction effects on available $\mathrm{N}$ are presented in Fig. 10. With regards to the effect of termination method, no differences in available $\mathrm{N}$ were observed between glyphosate terminated GM and incorporated GM. The exception was in 2008 when incorporated $\mathrm{CV}$ had significantly higher available $\mathrm{N}$ compared to glyphosate terminated CV. As well, in 2008 available $\mathrm{N}$ in incorporated $\mathrm{FP}$ in the $60-90 \mathrm{~cm}$ soil profile declined between late fall and spring while that in glyphosate-terminated FP increased slightly, resulting in a significant difference between the two treatments . Averaged over the three years, no differences in changes in available $\mathrm{N}$ between sampling periods between GM termination methods were observed.

\section{CONCLUSION}

The choice of green manure (GM) crops or the methods of termination (glyphosate or incorporation) had no effect on soil moisture, available $\mathrm{N}$ and exchangeable $\mathrm{P}$ at termination or the following spring; these factors were comparable to those observed under summerfallow, but were higher than on yellow pea and spring wheat stubble. GM seeding date had no effect on soil moisture, and available $\mathrm{N}$ and $\mathrm{P}$. Therefore, GM, terminated at full bloom, is a viable alternative to summerfallowing for the semiarid northern Great Plains and that GM crops could be seeded at any time during the growing season, allowing the producer flexibility to seed GM crops when it is most convenient for them to do so. GM could be terminated by either glyphosate or soil incorporation depending on which method is most appropriate for their farming practices. In addition, if seeded late, GM could be terminated by frost, thus saving on termination costs. Lateseeded GM used the least amount of soil water compared to early and mid-seeded GM crops 
which resulted in soil moisture levels closest to summerfallow in all three years. Hence, in a year when there is insufficient post-termination and overwinter precipitation, late-seeded GM would most likely conserve more soil moisture than early and mid-season GM crops.

While on average, no significant differences on soil moisture and available $\mathrm{N}$ were observed among GM crops tested in this study, some differences in growth characteristics were noted. Chickling vetch seemed to grow well at all seeding dates and would likely be the best choice if one had to seed late. In contrast, forage pea seemed to perform best when seeded early. Hence, among the three GM crops tested in this study, forage pea would be the GM of choice if one wants to seed the GM crop early. 


\section{Acknowledgments}

The authors acknowledge Duaine Messer, Don Sluth, Evan Powell, Ken Deobald, Cal McDonald, Lee Poppy, and Ray Leshures for chemical analysis and technical assistance;

Agriculture and Agri-Food Canada, and Barilla America for the support of data analysis and manuscript publication. 


\section{REFERENCES}

Biederbeck, V. O., Bouman, O. T., Looman, J., Slinkard, A. E., Bailey, L. D., Rice, W. A. and Janzen, H. H. 1993. Productivity of Four Annual Legumes as Green Manure in Dryland Cropping Systems. Agro. J. 85: 1035-1043.

Biederbeck, V. O. and Bouman, O. T. 1994. Water use by annual green manure legumes in dryland croppinf systems. Agro. J. 86: 543-549.

Brandt, S. A. 1996. Alternatives to summerfallow and subsequent wheat and barley yield on a Dark Brown soil. Can. J. Plant Sci. 76: 223-228.

Brandt, S. A. 1999. Management practices for black lentil green manure for the semi-arid Canadian prairies. Can. J. Plant Sci. 79: 11-17.

Campbell, C. A., Zentner, R. P., Basnyat, P., De Jong, R., Lemke, R., Desjardins, R. and Reiter, M. 2008. Nitrogen mineralization under summer fallow and continuous wheat in the semiarid Canadian prairie. Can. J. Soil Sci. 88: 681-696.

Campbell, C. A., Zentner, R. P., Basnyat, P., Wang, H., Selles, F., McConkey, B. G., Gan, Y. T. and Cutforth, H. W. 2007. Water use efficiency and water and nitrate distribution in soil in the semiarid prairie: Effect of crop type over 21 years. Can. J. Plant Sci. 87: 815-827.

Campbell, C. A., Selles, F., Lafond, G. P., Biederbeck, V. O. and Zentner, R. P. 2001. Tillage Fertilizer changes: Effect on some soil quality attributes under long-term crop rotations in a thin Black Chernozem. Can. J. Soil Sci. 81: 157-165.

Curtin, D., Wang, H., Selles, F., Zentner, R. P., Biederbeck, V. O. and Campbell, C. A. 2000. Legume green manure as partial fallow replacement in semiarid Saskatchewan: Effect on carbon fluxes. Can. J. Soil Sci. 80: 499-505. 
Cutforth, H. W., Angadi, S. V., McConkey, B. G., Miller, P. R., Ulrich, D., Gulden, R., Volkmar, K. M., Entz, M. H. and Brandt, S. A. 2013. Comparing rooting characteristics and soil water withdrawal patterns of wheat with alternative oilseed and pulse crops grown in the semiarid Canadian prairie. Can. J. Soil Sci. 93: 147-160.

De Jong, R., Campbell, C. A., Zentner, R. P., Basnyat, P., Cutforth, H. and Desjardins, R. 2008. Quantifying soil water conservation in the semiarid region of Saskatchewan, Canada: Effect of fallow frequency and N fertilizer. Can. J. Soil Sci. 88: 461-475.

Fernandez, G. C. J, 2007. Design and analysis of commonly used comparative horticultural experiments. HortScience 42: 1052-1069.

Gan, Y. T., Campbell, C. A., Liu, L., Basnyat, P. and McDonald, C. L. 2009. Water use and distribution profile under pulse and oilseed crops in semiarid northern high latitude areas.", Agric. Water Management 96: 337-348.

Gan, Y. T., Hamel, C., O'Donovan, J. T., Cutforth, H. W., Zentner, R. P., Campbell, C. A., Niu, Y. and Poppy, L. B. 2015. Diversifying crop rotations with pulses enhances system productivity. Scientific Reports 5: 14625.

Gan, Y., Liang, C., Chai, Q., Lemke, R. L., Campbell, C. A. and Zentner, R. P. 2014. Improving farming practices reduces the carbon footprint of spring wheat production. Nature Comm. 5: 5012.

Gan, Y. T., Liu, L., Cutforth, H. W., Wang, X-Y., and Ford, G. 2011. Vertical distribution profiles and temporal growth patterns of roots in selected oilseeds, pulses and spring wheat. Crop and Pasture Sci. 62: 457-466. 
Gan, Y., Mooleki, S. P., Lemke, R. L., Zentner, R. P. and Ruan, Y. 2016. Durum Wheat productivity in response to soil water and soil residual $\mathrm{N}$ associated with previous crop management. Agro. J. 108 (4): (in press).

Hunt, J. R., Browne, C., McBeath, T. M., Verburg, K., Craig, S. and Whitbread, A. M. 2013. Summer fallow weed control and residue management impacts on winter crop yield though soil water and $\mathrm{N}$ accumulation in a winter-dominant, low rainfall region of southern Australia. Crop and Pasture Sci. 64: 922-934.

Keeney, D. R. and Nelson, D.W. 1982. Nitrogen - inorganic forms. In A. L. Page (eds.) Methods of soil analysis, Part 2. Agron. Monogr. 9, $2^{\text {nd }}$ ed. ASA and SSSA, Madison, WI. p. 643-698.

Kirkegaard, J. A. and Ryan, M. H. 2014. Magnitude and mechanisms of persistent crop sequence effects on wheat. Field Crops Res. 164: 154-165.

Lemke, R. L., Vandenbygaart, A. J., Campbell, C. A., Lafond, G. P., McConkey, B. G. and Grant, B. 2012. Long-term effects of crop rotations and fertilization on soil $\mathrm{C}$ and $\mathrm{N}$ in a thin Black Chernozem in southeastern Saskatchewan. Can. J. of Soil Sci. 92: 449-461.

Littell, R.C., G.A. Milliken, W.W. Stroup, and R.D. Wolfinger. 2006. SAS System for mixed models ( $2^{\text {nd }}$ ed.). SAS Institute, Cary NC:

Miller, P. R., Brandt, S. A., McDonald, C. L. and Waddington, J. 2006. Chickpea, lentil, and pea response to delayed spring seeding on the Northern Great Plains. Can. J. Plant Sci. 86: 10591070.

Panettieri, M., Knicker, H., Murillo, J. M., Madejón, E. and Hatcher, P. G. 2014. Soil organic matter degradation in an agricultural chronosequence under different tillage regimes 
evaluated by organic matter pools, enzymatic activities and CPMAS 13C NMR. Soil Biol. and Biochem. 78: 170-181.

Pikul, J. L., Aase, J. K. and Cochran, V. L. 1997. Lentil green manure as fallow replacement in the semiarid northern Great Plains. Agron. J. 89: 867-874.

Ramnarine, R., Voroney, R. P., Wagner-Riddle, C. and Dunfield, K. E. 2015. Conventional and no-tillage effects on the distribution of crop residues and light fraction organic matter. Soil Sci. Soc. of Am. J. 79: 74-80.

Roper, M. M. Milroy, S. P. and Poole, M. L. 2012. Green and brown manures in dryland wheat production systems in Mediterranean-type environments. Adv. Agron. 117: 275-313.

Tanaka, D. L. and Aase, J. K. 1987. Fallow method influences on soil water and precipitation storage efficiency. Soil and Till. Res. 9: 307-316.

Williams, P., Sobering, D. and Antoniszyn, J. 1998. Protein testing methods at the Canadian Grain Commission. In Wheat Protein Symposium: proceedings; 1998 March 9-10. Saskatoon, SK.

Zentner, R. P., Basnyat, P., Brandt, S. A., Thomas, A. G., Ulrich, D., Campbell, C. A., Nagy, C. N., Frick, B., Lemke, R., Malhi, S. S. and others. 2011. Effects of input management and crop diversity on economic returns and riskiness of cropping systems in the semi-arid Canadian Prairie. Renewable Agri. and Food Syst. 26: 208-223.

Zentner, R. P., Campbell, C. A., Biederbeck, V. O. and Selles, F. 1996. Indianhead black lentil as green manure for wheat rotations in the Brown soil zone. Can. J. Plant Sci. 76: 417-422.

Zentner, R. P., Campbell, C. A., Biederbeck, V. O., Selles, F., Lemke, R., Jefferson, P. G. and Gan, Y. 2004. Long-term assessment of management of an annual legume green manure crop for fallow replacement in the Brown soil zone. Can. J. Plant Sci. 84: 11-22. 


\section{Figure Caption}

Fig.1. Monthly precipitation at Swift Current during the growing season (April to September) for 2006, 2007, 2008 and 30 year normal (1971 - 2000) (A) and total precipitation received up to termination/harvest and late fall for 2006, 2007 and 2008 (B).

Fig. 2. Characteristics of different green manure (GM) crops (forage pea $[\mathrm{FP}]$, chickling vetch [CV], and black lentil [BL] seeded early, mid and late summer at termination, FP cut for silage (Slg), and straw of yellow pea [YP] and spring wheat [SW] harvested (Harv) for grain. Error bars represent Tukey's Honestly Significant Differences (HSD) at $\alpha<0.05$ level of significance.

Fig. 3. Effect of different green manure crops (forage pea $[\mathrm{FP}]$, chickling vetch $[\mathrm{CV}]$, and black lentil [BL] seeded early [E], mid [M] and late [L], FP cut for silage (Slg), straw of yellow pea [YP] and spring wheat [SW] harvested (Harv) for grain, and conventional summerfallow on water use and soil water at termination, late fall and following spring. Error bars represent Tukey's Honestly Significant Differences (HSD) at $\alpha<0.05$ level of significance.

Fig. 4. Effect of different green manure crops (forage pea [FP], chickling vetch $[\mathrm{CV}]$, and black lentil [BL] seeded early [E], mid [M] and late [L], FP cut for silage (Slg), straw of yellow pea [YP] and spring wheat [SW] harvested (Harv) for grain, and conventional summerfallow on changes in soil water between termination and late fall, late fall and spring, and termination and spring. Error bars represent Tukey's Honestly Significant Differences (HSD) at $\alpha<0.05$ level of significance. 
Fig. 5. Effect of different green manure crops (forage pea [FP], chickling vetch [CV], and black lentil [BL] seeded early [E], mid [M] and late [L], FP cut for silage (Slg), straw of yellow pea [YP] and spring wheat [SW] harvested (Harv) for grain, and conventional summerfallow on available $\mathrm{N}$ at termination, late fall and following spring. Error bars represent Tukey's Honestly Significant Differences (HSD) at $\alpha<0.05$ level of significance.

Fig. 6. Effect of different green manure crops (forage pea [FP], chickling vetch [CV], and black lentil [BL] seeded early [E], mid [M] and late [L], FP cut for silage (Slg), straw of yellow pea [YP] and spring wheat [SW] harvested (Harv) for grain, and conventional summerfallow on changes in available $\mathrm{N}$ between termination and late fall, late fall and spring, and termination and spring. Error bars represent Tukey's Honestly Significant Differences (HSD) at $\alpha<0.05$ level of significance.

Fig. 7. Effect of different green manure crops (forage pea [FP], chickling vetch $[\mathrm{CV}]$, and black lentil [BL] seeded early [E], mid [M] and late [L], FP cut for silage (Slg), straw of yellow pea [YP] and spring wheat [SW] harvested (Harv) for grain, and conventional summerfallow on exchangeable $\mathrm{P}$ at termination, late fall and following spring. Error bars represent Tukey's Honestly Significant Differences (HSD) at $\alpha<0.05$ level of significance.

Fig. 8. Soil depths at which soil water, soil water use and changes in soil water between sampling periods exhibited year by treatment interaction effect. Error bars represent Tukey's Honestly Significant Differences (HSD) at $\alpha<0.05$ level of significance.

Fig. 9. Comparing effect of green manure crops (forage pea $[\mathrm{FP}]$, chickling vetch $[\mathrm{CV}]$, and black lentil $[\mathrm{BL}]$ ) terminated by early glyphosate [Gly] or incorporation [Inc] with stubble of yellow peas [YP] and spring wheat [SW] harvested [Harv] for grain, forage peas cut for silage 
[Slg] and conventional fallow [Fallow] on soil water at termination, late fall, following spring and recharge between fall and spring averaged over three seasons, 2006, 2007 and 2008. Error bars represent Tukey's Honestly Significant Differences (HSD) at $\alpha<0.05$ level of significance.

Fig. 10. Soil depths at which available nitrogen and changes in available nitrogen between sampling periods exhibited year by treatment interaction effect. Error bars represent Tukey's Honestly Significant Differences (HSD) at $\alpha<0.05$ level of significance.

Fig. 11. Comparing effect of green manure crops (forage pea $[\mathrm{FP}]$, chickling vetch $[\mathrm{CV}]$, and black lentil $[\mathrm{BL}])$ terminated by early glyphosate [Gly] or incorporation [Inc] with stubble of yellow peas $[\mathrm{YP}]$ and spring wheat $[\mathrm{SW}]$ harvested [Harv] for grain, forage peas cut for silage [Slg] and conventional fallow [Fallow] on available N averaged over three seasons, 2006, 2007 and 2008. Error bars represent Tukey's Honestly Significant Differences (HSD) at $\alpha<0.05$ level of significance. 
Table 1. Treatments used in the study showing green manure and harvested grain crops, dates of seeding, duration and method of termination.

\begin{tabular}{|c|c|c|c|c|c|c|c|c|c|c|c|c|}
\hline \multirow{2}{*}{$\begin{array}{c}\text { Treat. } \\
\text { \# }\end{array}$} & \multirow{2}{*}{ Abbrev. } & \multirow{2}{*}{ Crop } & \multirow{2}{*}{$\begin{array}{c}\text { Termination } \\
\text { Method }\end{array}$} & \multicolumn{3}{|c|}{ Seeding date } & \multicolumn{3}{|c|}{ Termination date } & \multicolumn{3}{|c|}{ Duration (weeks) } \\
\hline & & & & 2006 & 2007 & 2008 & 2006 & 2007 & 2008 & 2006 & 2007 & 2008 \\
\hline 1 & FPGly & Forage pea & & \multirow{6}{*}{ 05-May } & \multirow{6}{*}{ 08-May } & \multirow{6}{*}{ 13-May } & \multirow{6}{*}{ 05-Jul } & \multirow{6}{*}{ 04-Jul } & \multirow{6}{*}{ 21-Jul } & \multirow{6}{*}{9} & \multirow{6}{*}{8} & \multirow{6}{*}{10} \\
\hline 2 & CVGly & Chickling vetch & Glyphosate & & & & & & & & & \\
\hline 3 & BLGly & Black lentil & & & & & & & & & & \\
\hline 4 & FPInc & Forage pea & \multirow{3}{*}{ Incorporated } & & & & & & & & & \\
\hline 5 & CVInc & Chickling vetch & & & & & & & & & & \\
\hline 6 & BLInc & Black lentil & & & & & & & & & & \\
\hline 7 & FPGly & Forage pea & \multirow{3}{*}{ Glyphosate } & \multirow{3}{*}{ 04-Jul } & \multirow{3}{*}{ 03-Jul } & \multirow{3}{*}{ 27-Jun } & \multirow{3}{*}{ 22-Aug } & \multirow{3}{*}{ 21-Aug } & \multirow{3}{*}{ 08-Sep } & \multirow{3}{*}{7} & \multirow{3}{*}{7} & \multirow{3}{*}{10} \\
\hline 8 & CVGly & Chickling vetch & & & & & & & & & & \\
\hline 9 & BLGly & Black lentil & & & & & & & & & & \\
\hline 10 & FPGly & Forage pea & \multirow{3}{*}{$\begin{array}{l}\text { Glyphosate or } \\
\text { Frost }\end{array}$} & \multirow{3}{*}{ 20-Jul } & \multirow{3}{*}{ 26-Jul } & \multirow{3}{*}{ 31-Jul } & \multirow{3}{*}{ 19-Sep } & \multirow{3}{*}{ 20-Sep } & \multirow{3}{*}{ 09-Oct } & & & \\
\hline 11 & CVGly & Chickling vetch & & & & & & & & 9 & 8 & 10 \\
\hline 12 & BLGly & Black lentil & & & & & & & & & & \\
\hline 13 & YPHarv & Yellow pea & Straight & & $(0$ & & $02-\Delta u r$ & $02-{ }_{0}$ & 20-Aug & 13 & 13 & 13 \\
\hline 14 & SWHarv & Spring wheat & combined & 05-May & 08-May & 13-May & OL-Aug & 0L-Aug & 09-Sep & 13 & 13 & 16 \\
\hline 15 & FPSlg & Forage pea & Silage & & & & 12-Jul & 18-Jul & 21-Jul & 10 & 10 & 10 \\
\hline 16 & SF & Summerfallow & & & & & & & & & & \\
\hline
\end{tabular}


Table 2. Analysis of variance table showing p-values: green manure timing effect

\begin{tabular}{|c|c|c|c|c|c|c|c|c|c|c|c|}
\hline \multirow[b]{3}{*}{ Source } & \multirow[b]{3}{*}{$\mathrm{DF}$} & \multicolumn{10}{|c|}{ Soil water and water use at various depths $(\mathrm{cm})$} \\
\hline & & \multicolumn{5}{|c|}{ Soil water at termination/harvest } & \multicolumn{5}{|c|}{ Soil water in late fall } \\
\hline & & $0-15 \mathrm{~cm}$ & $15-30 \mathrm{~cm}$ & $30-60 \mathrm{~cm}$ & $60-90 \mathrm{~cm}$ & $90-120 \mathrm{~cm}$ & $0-15 \mathrm{~cm}$ & $15-30 \mathrm{~cm}$ & $30-60 \mathrm{~cm}$ & $60-90 \mathrm{~cm}$ & $90-120 \mathrm{~cm}$ \\
\hline $\mathrm{Yr}$ & 2 & $<0.001$ & 0.002 & 0.231 & 0.001 & 0.009 & $<0.001$ & $<0.001$ & $<0.001$ & 0.009 & $<0.001$ \\
\hline Trt & 12 & $<0.001$ & $<0.001$ & $<0.001$ & $<0.001$ & $<0.001$ & 0.001 & $<0.001$ & $<0.001$ & 0.008 & 0.120 \\
\hline \multirow[t]{2}{*}{ Yr*Trt } & 24 & $<0.001$ & $<0.001$ & 0.002 & $<0.001$ & 0.010 & $<0.001$ & $<0.001$ & $<0.001$ & 0.045 & 0.239 \\
\hline & & \multicolumn{5}{|c|}{ Soil water following spring } & \multicolumn{5}{|c|}{ Change in soil water between termination and late fall } \\
\hline Yr & 2 & $<0.001$ & $<0.001$ & $<0.001$ & $<0.001$ & 0.031 & $<0.001$ & $<0.001$ & $<0.001$ & $<0.001$ & $<0.001$ \\
\hline Trt & 12 & 0.011 & 0.001 & $<0.001$ & $<0.001$ & 0.012 & $<0.001$ & $<0.001$ & 0.001 & $<0.001$ & 0.009 \\
\hline \multirow[t]{2}{*}{ Yr*Trt } & 24 & 0.197 & 0.001 & 0.122 & 0.867 & 0.593 & $<0.001$ & $<0.001$ & $<0.001$ & 0.001 & 0.187 \\
\hline & & \multicolumn{5}{|c|}{ Change in soil water between late fall and spring } & \multicolumn{5}{|c|}{ Change in soil water between termination and spring } \\
\hline $\mathrm{Yr}$ & 2 & $<0.001$ & $<0.001$ & $<0.001$ & $<0.001$ & $<0.001$ & $<0.001$ & $<0.001$ & $<0.001$ & 0.057 & 0.002 \\
\hline Trt & 12 & $<0.001$ & 0.013 & 0.139 & 0.162 & 0.250 & $<0.001$ & $<0.001$ & 0.001 & 0.054 & 0.078 \\
\hline \multirow[t]{2}{*}{ Yr*Trt } & 24 & 0.044 & 0.115 & 0.263 & 0.137 & 0.097 & $<0.001$ & $<0.001$ & 0.129 & 0.070 & 0.282 \\
\hline & & \multicolumn{5}{|c|}{ Soil water use at termination/harvest } & \multicolumn{3}{|c|}{$\begin{array}{c}\text { Total water use at } \\
\text { termination }(0-120 \mathrm{~cm}) \\
<0.001\end{array}$} & \multicolumn{2}{|c|}{$\begin{array}{l}\text { Total water uptake at } \\
\text { termination }\end{array}$} \\
\hline Yr & 2 & $<0.001$ & $<0.001$ & $<0.001$ & $<0.001$ & $<0.001$ & $<$ & 1 & & & \\
\hline Trt & 12 & $<0.001$ & $<0.001$ & $<0.001$ & $<0.001$ & $<0.001$ & & & & & \\
\hline \multirow[t]{3}{*}{ Yr*Trt } & 24 & $<0.001$ & $<0.001$ & $<0.001$ & $<0.001$ & 0.018 & & & & & \\
\hline & & \multicolumn{10}{|c|}{ Available Nitrogen } \\
\hline & & \multicolumn{5}{|c|}{ Available $\mathrm{N}$ at termination/harvest } & \multicolumn{5}{|c|}{ Available $\mathrm{N}$ in late fall } \\
\hline Yr & 2 & $<0.001$ & 0.004 & $<0.001$ & $<0.001$ & $<0.001$ & $<0.001$ & $<0.001$ & $<0.001$ & $<0.001$ & $<0.001$ \\
\hline Trt & 12 & $<0.001$ & $<0.001$ & 0.114 & 0.954 & 0.056 & $<0.001$ & $<0.001$ & $<0.001$ & 0.250 & 0.116 \\
\hline \multirow[t]{2}{*}{ Yr*Trt } & 24 & $<0.001$ & 0.016 & 0.001 & 0.790 & 0.358 & $<0.001$ & $<0.001$ & 0.165 & 0.915 & 0.916 \\
\hline & & \multicolumn{5}{|c|}{ Available $\mathrm{N}$ following spring } & \multicolumn{5}{|c|}{ Change available $\mathrm{N}$ between termination and late fall } \\
\hline Yr & 2 & $<0.001$ & $<0.001$ & $<0.001$ & $<0.001$ & $<0.001$ & 0.030 & $<0.001$ & 0.001 & 0.005 & $<0.001$ \\
\hline Trt & 12 & $<0.001$ & $<0.001$ & 0.029 & 0.344 & 0.578 & $<0.001$ & $<0.001$ & 0.045 & 0.978 & 0.243 \\
\hline \multirow[t]{2}{*}{ Yr*Trt } & 24 & 0.082 & 0.002 & 0.056 & 0.605 & 0.705 & 0.045 & $<0.001$ & 0.057 & 0.984 & 0.863 \\
\hline & & \multicolumn{5}{|c|}{ Change available $\mathrm{N}$ between late fall and spring } & \multicolumn{5}{|c|}{ Change available $\mathrm{N}$ between termination and spring } \\
\hline $\mathrm{Yr}$ & 2 & $<0.001$ & $<0.001$ & 0.014 & $<0.001$ & $<0.001$ & $<0.001$ & $<0.001$ & 0.156 & 0.271 & 0.536 \\
\hline
\end{tabular}




\begin{tabular}{|c|c|c|c|c|c|c|c|c|c|c|c|}
\hline Trt & 12 & 0.834 & 0.401 & 0.147 & 0.569 & 0.526 & $<0.001$ & $<0.001$ & 0.173 & 0.781 & 0.252 \\
\hline Yr*Trt & 24 & 0.938 & 0.167 & 0.224 & 0.351 & 0.737 & 0.166 & 0.006 & 0.220 & 0.834 & 0.366 \\
\hline & & \multicolumn{10}{|c|}{ Exchangeable Phosphorus } \\
\hline & & \multicolumn{5}{|c|}{ Exchangeable $\mathrm{P}$ at termination/harvest } & \multicolumn{5}{|c|}{ Exchangeable $\mathrm{P}$ in late fall } \\
\hline $\mathrm{Yr}$ & 2 & 0.040 & 0.660 & 0.030 & 0.040 & 0.655 & 0.162 & 0.889 & 0.238 & $<0.001$ & $<0.001$ \\
\hline Trt & 12 & 0.097 & 0.040 & 0.733 & 0.344 & 0.338 & 0.048 & 0.329 & 0.016 & 0.428 & 0.555 \\
\hline Yr*Trt & 24 & 0.206 & 0.901 & 0.214 & 0.001 & 0.015 & 0.026 & 0.319 & 0.670 & 0.931 & 0.326 \\
\hline & & \multicolumn{5}{|c|}{ Exchangeable $\mathrm{P}$ following spring } & \multicolumn{5}{|c|}{ Change exchangeable $\mathrm{P}$ between termination and late fall } \\
\hline Yr & 2 & 0.011 & 0.047 & $<0.001$ & $<0.001$ & $<0.001$ & 0.003 & 0.603 & 0.230 & 0.532 & 0.021 \\
\hline Trt & 12 & 0.389 & 0.872 & 0.007 & 0.743 & 0.174 & 0.063 & 0.181 & 0.373 & 0.556 & 0.183 \\
\hline Yr*Trt & 24 & 0.403 & 0.448 & 0.025 & 0.257 & 0.742 & 0.063 & 0.924 & 0.075 & 0.032 & 0.007 \\
\hline & & \multicolumn{5}{|c|}{ Change exchangeable $\mathrm{P}$ between late fall and spring } & \multicolumn{5}{|c|}{ Change exchangeable $\mathrm{P}$ between termination and spring } \\
\hline Yr & 2 & $<0.001$ & 0.079 & $<0.001$ & $<0.001$ & $<0.001$ & 0.905 & 0.117 & $<0.001$ & $<0.001$ & $<0.001$ \\
\hline Trt & 12 & 0.085 & 0.874 & 0.364 & 0.728 & 0.272 & 0.232 & 0.088 & 0.434 & 0.345 & 0.016 \\
\hline Yr*Trt & 24 & 0.206 & 0.582 & 0.199 & 0.534 & 0.721 & 0.703 & 0.853 & 0.099 & 0.006 & 0.027 \\
\hline
\end{tabular}


Table 3. Analysis of variance table showing p-values: termination method effect

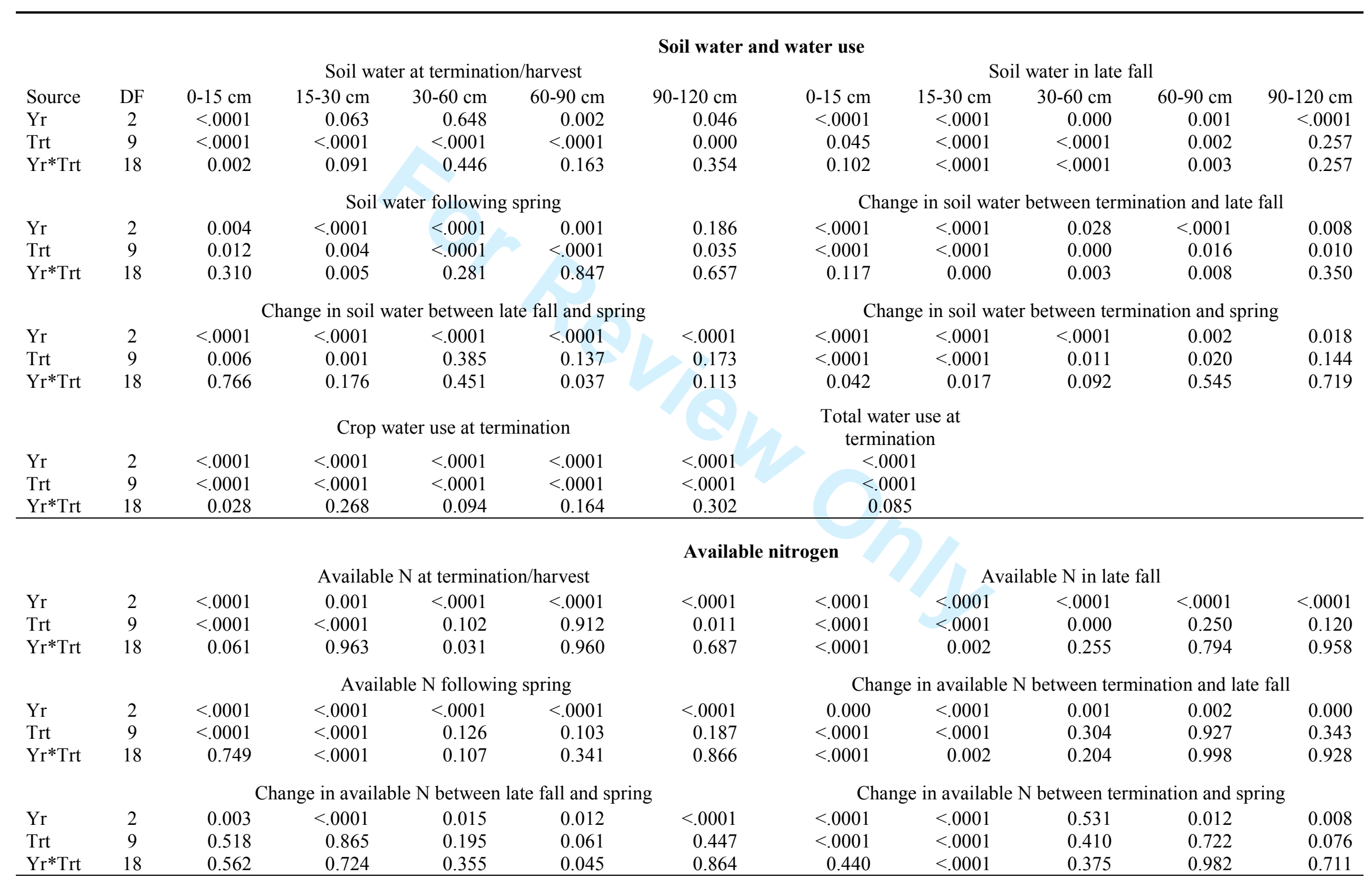




\section{Exchangeable Phosphorus}

Exchangeable $\mathrm{P}$ at termination/harvest

$\begin{array}{lccccc}\text { Yr } & 2 & 0.106 & 0.252 & 0.207 & 0.003 \\ \text { Trt } & 9 & 0.037 & 0.075 & 0.668 & 0.912 \\ \text { Yr*Trt } & 18 & 0.467 & 0.764 & 0.686 & 0.115\end{array}$

$0.230 \quad 0.441$

Exchangeable $\mathrm{P}$ in late fall

$0.223 \quad 0.329$

Exchangeable $\mathrm{P}$ following spring

$\begin{array}{lcc}\text { Yr } & 2 & 0.077 \\ \text { Trt } & 9 & 0.171 \\ \text { Yr*Trt } & 18 & 0.766\end{array}$

$\begin{array}{rrr}0.168 & <.0001 & <.0001 \\ 0.878 & 0.001 & 0.957 \\ 0.649 & 0.162 & 0.949\end{array}$

Change in exchangeable $\mathrm{P}$ between late fall and spring

\begin{tabular}{lcc} 
Yr & 2 & 0.036 \\
Trt & 9 & 0.137 \\
Yr*Trt & 18 & 0.044 \\
\hline
\end{tabular}

$\begin{array}{rrr}0.139 & <.0001 & <.0001 \\ 0.822 & 0.367 & 0.859 \\ 0.638 & 0.772 & 0.995\end{array}$

0.995

0.064

0.067

0.241

0.193

0.030

0.010

0.003

.

0.318

0.761

0.972

0.342

Change in exchangeable $\mathrm{P}$ between termination and late fall

$\begin{array}{llllll}0.000 & 0.040 & 0.116 & 0.837 & 0.195 & 0.481 \\ 0.135 & 0.134 & 0.529 & 0.296 & 0.840 & 0.056 \\ 0.663 & 0.066 & 0.640 & 0.301 & 0.428 & 0.015\end{array}$

Change in exchangeable $\mathrm{P}$ between termination and spring

\begin{tabular}{lllrl}
0.782 & 0.020 & 0.001 & $<.0001$ & 0.001 \\
0.046 & 0.365 & 0.490 & 0.932 & 0.019 \\
0.829 & 0.890 & 0.712 & 0.210 & 0.041 \\
\hline
\end{tabular}



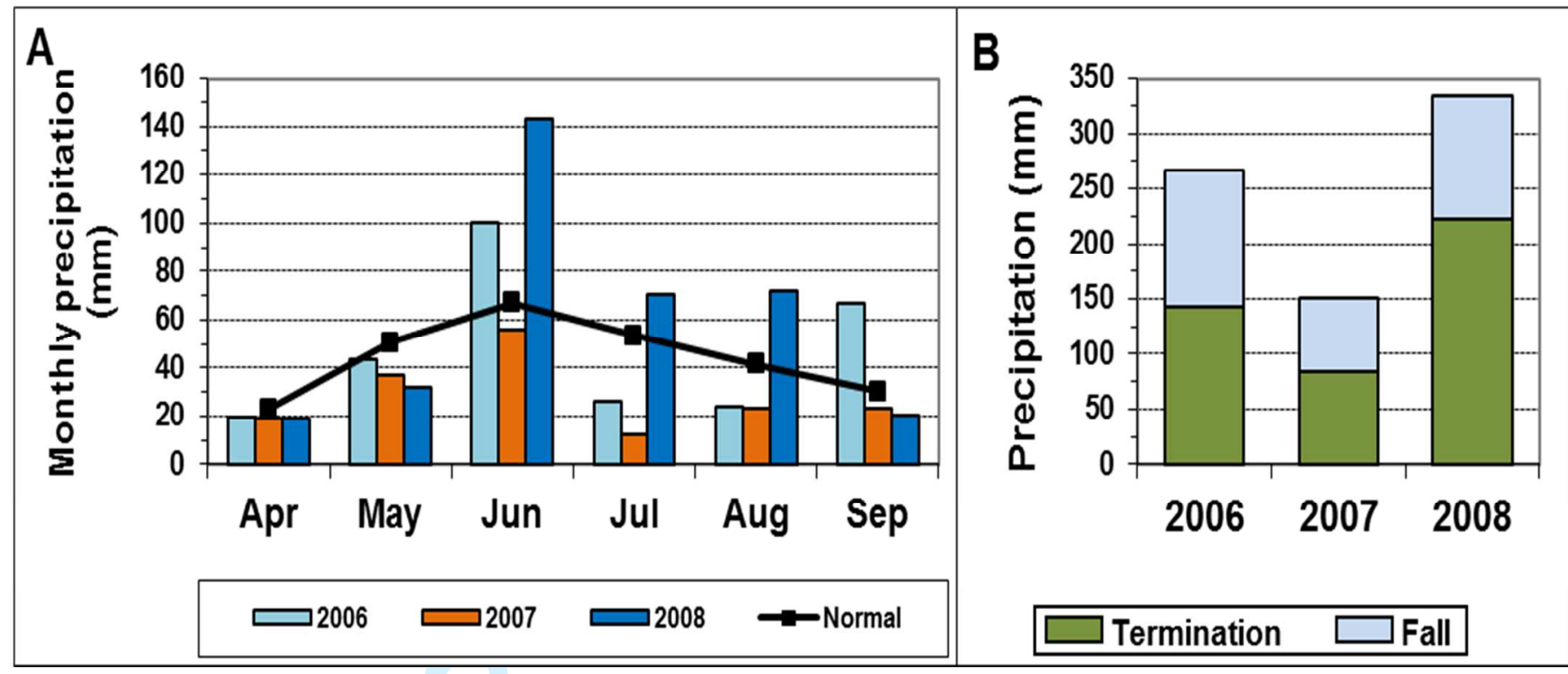

Fig.1. Monthly precipitation at Swift Current during the growing season (April to September) for 2006, 2007, 2008 and 30 year normal (1971 - 2000) (A) and total precipitation received up to termination/harvest and late fall for 2006, 2007 and 2008 (B). 


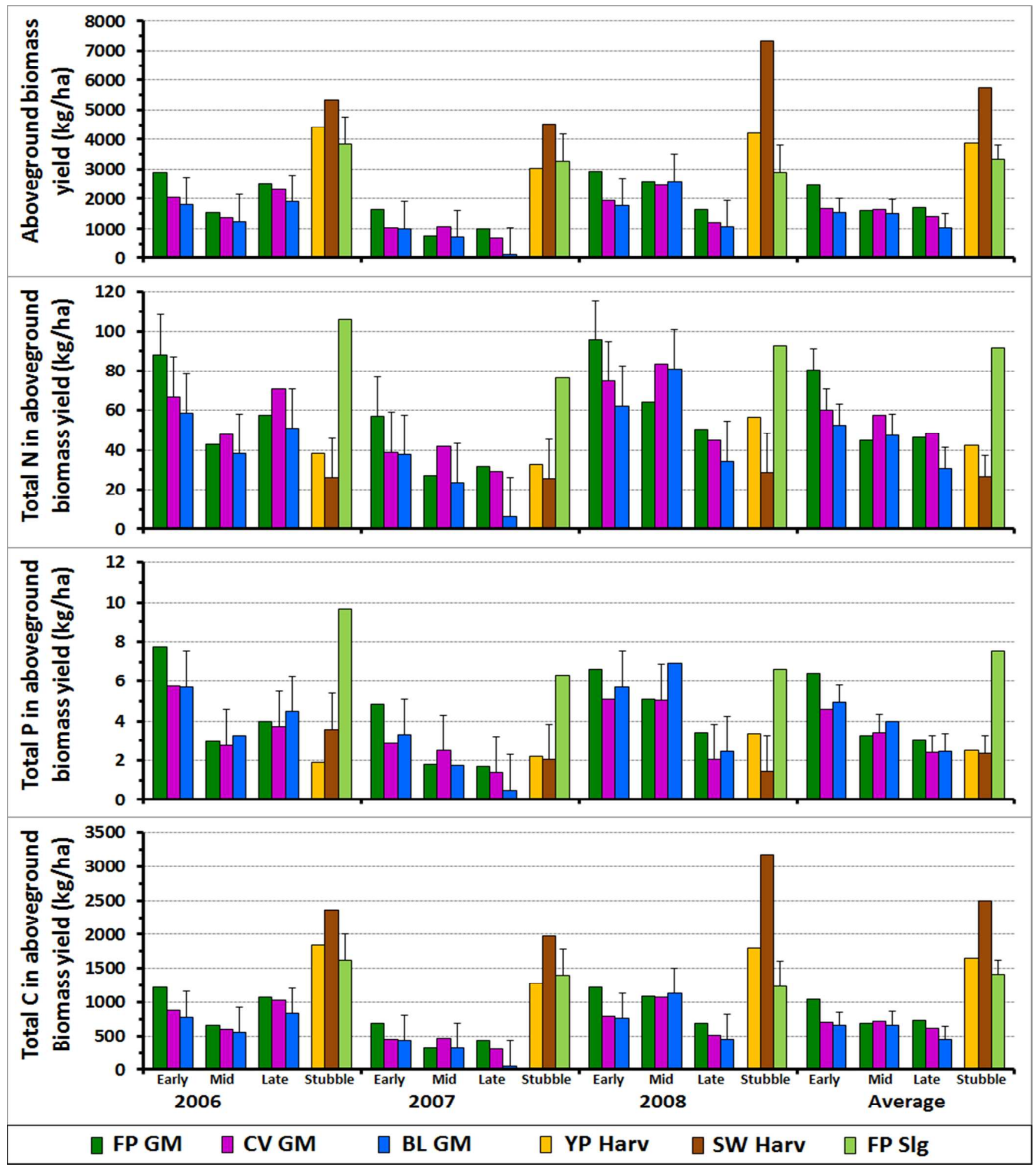

Fig. 2. Characteristics of different green manure (GM) crops (forage pea [FP], chickling vetch [CV], and black lentil [BL] seeded early, mid and late summer at termination, FP cut for silage (Slg), and straw of yellow pea [YP] and spring wheat [SW] harvested (Harv) for grain. Error bars represent Tukey's Honestly Significant Differences (HSD) at $\alpha<0.05$ level of significance. 


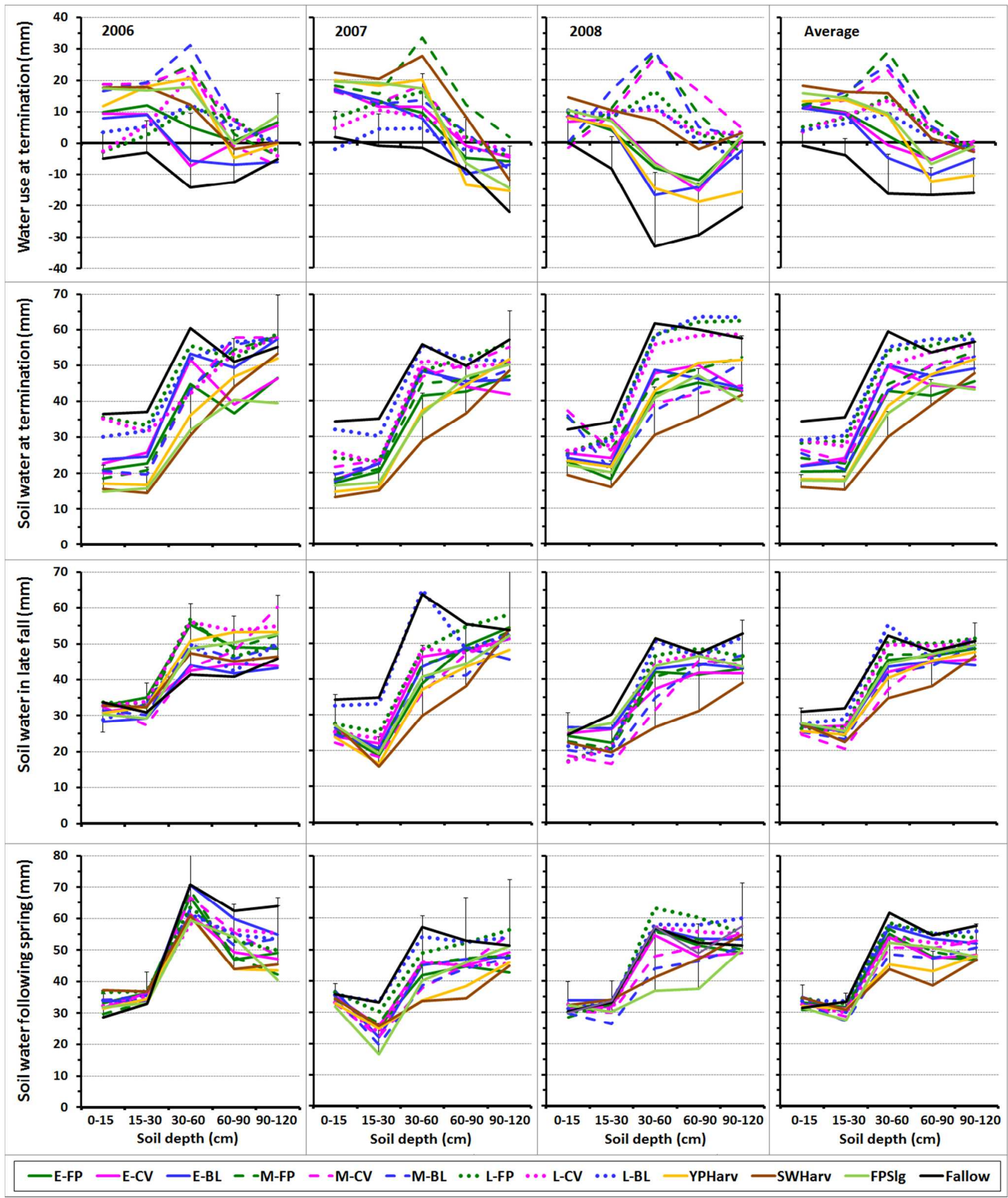

Fig. 3. Effect of different green manure crops (forage pea $[\mathrm{FP}]$, chickling vetch $[\mathrm{CV}]$, and black lentil [BL] seeded early [E], mid [M] and late [L], FP cut for silage (Slg), straw of yellow pea [YP] and spring wheat [SW] harvested (Harv) for grain, and conventional summerfallow on water use and soil water at termination, late fall and following spring. Error bars represent Tukey's Honestly Significant Differences (HSD) at $\alpha<0.05$ level of significance. 

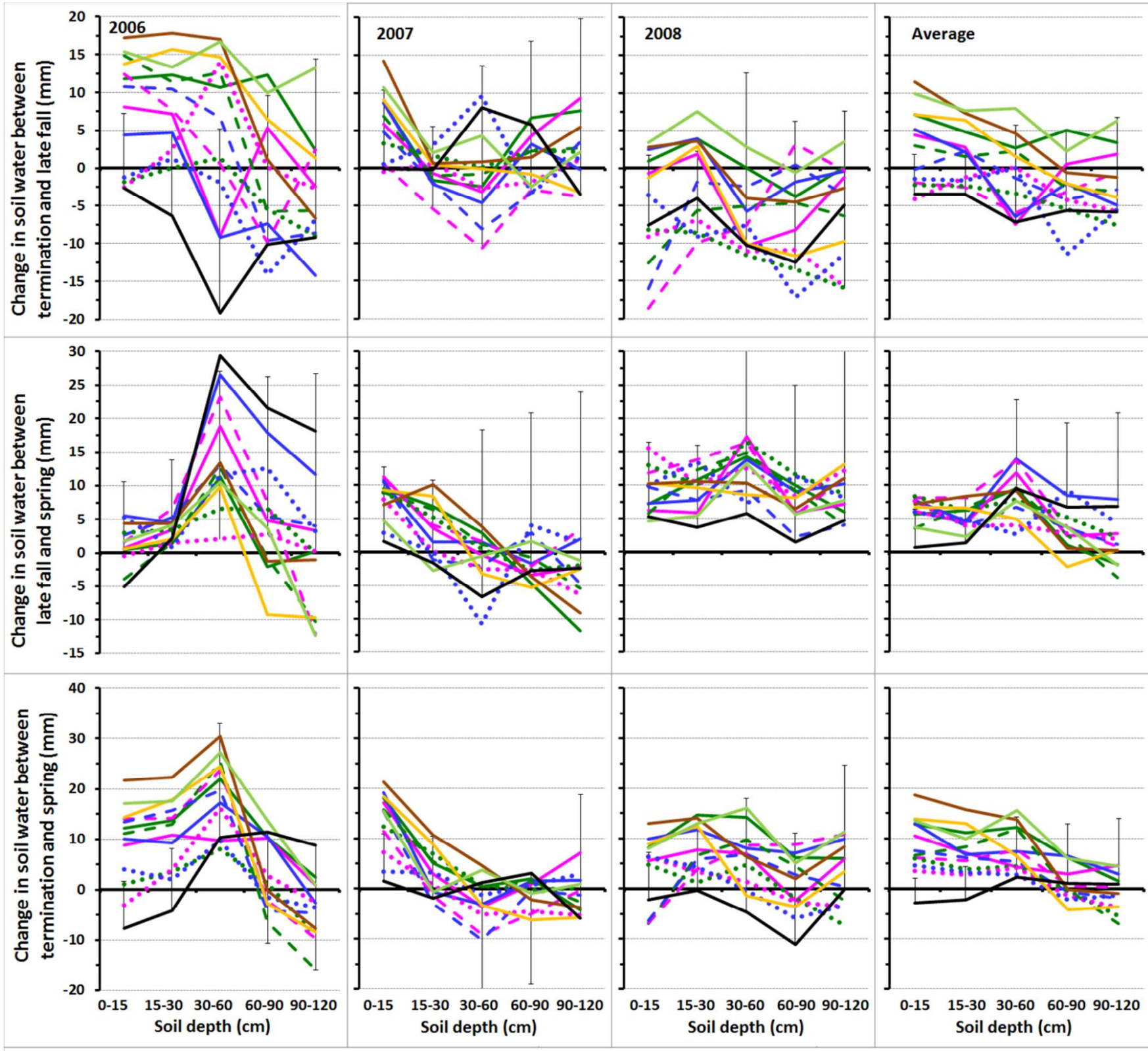

—E-FP —E-CV —E-BL - -M-FP - -M-CV - -M-BL $\cdots$ L-FP $\cdots$ L-CV $\cdots$ L-BL — YPHarv —SWHarv — FPSIg —Fallow

Fig. 4. Effect of different green manure crops (forage pea [FP], chickling vetch [CV], and black lentil [BL] seeded early [E], mid [M] and late [L], FP cut for silage (Slg), straw of yellow pea [YP] and spring wheat [SW] harvested (Harv) for grain, and conventional summerfallow on changes in soil water between termination and late fall, late fall and spring, and termination and spring. Error bars represent Tukey's Honestly Significant Differences (HSD) at $\alpha<0.05$ level of significance. 


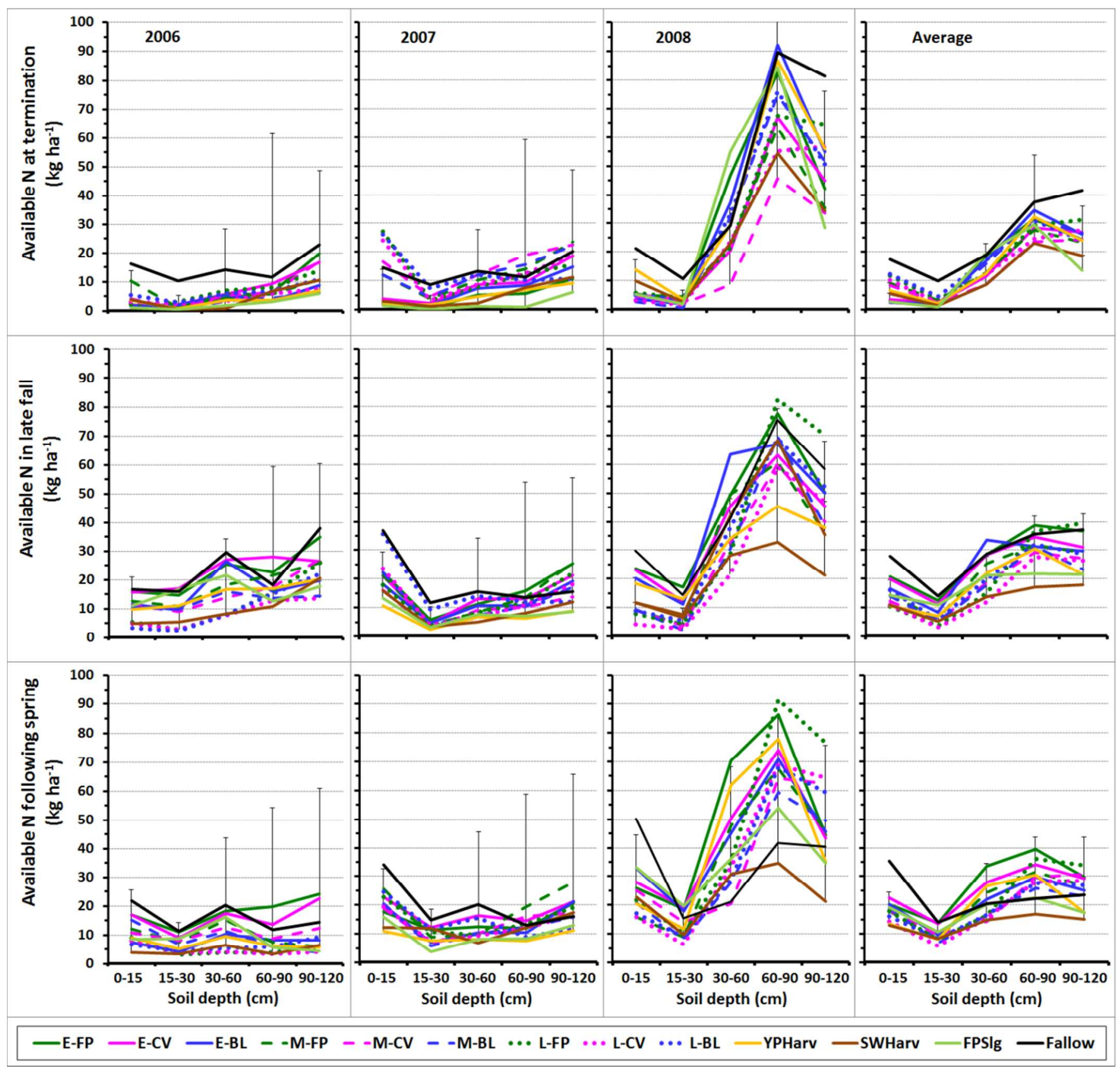

Fig. 5. Effect of different green manure crops (forage pea [FP], chickling vetch [CV], and black lentil [BL] seeded early [E], mid [M] and late [L], FP cut for silage (Slg), straw of yellow pea [YP] and spring wheat [SW] harvested (Harv) for grain, and conventional summerfallow on available $\mathrm{N}$ at termination, late fall and following spring. Error bars represent Tukey's Honestly Significant Differences (HSD) at $\alpha<0.05$ level of significance. 

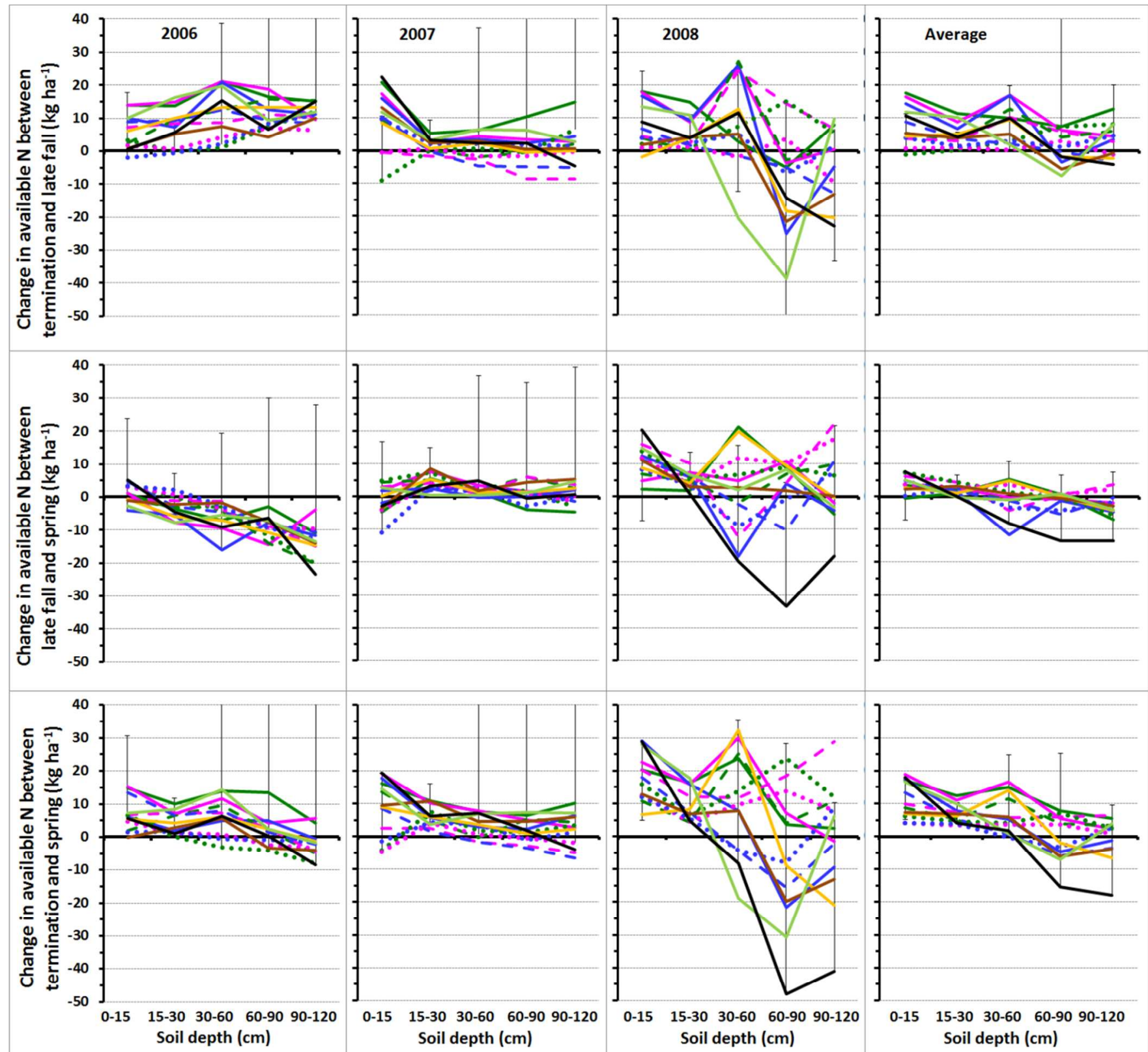

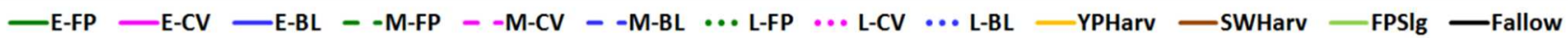

Fig. 6. Effect of different green manure crops (forage pea [FP], chickling vetch [CV], and black lentil [BL] seeded early [E], mid [M] and late [L], FP cut for silage (Slg), straw of yellow pea [YP] and spring wheat [SW] harvested (Harv) for grain, and conventional summerfallow on changes in available $\mathrm{N}$ between termination and late fall, late fall and spring, and termination and spring. Error bars represent Tukey's Honestly Significant Differences (HSD) at $\alpha<0.05$ level of significance. 


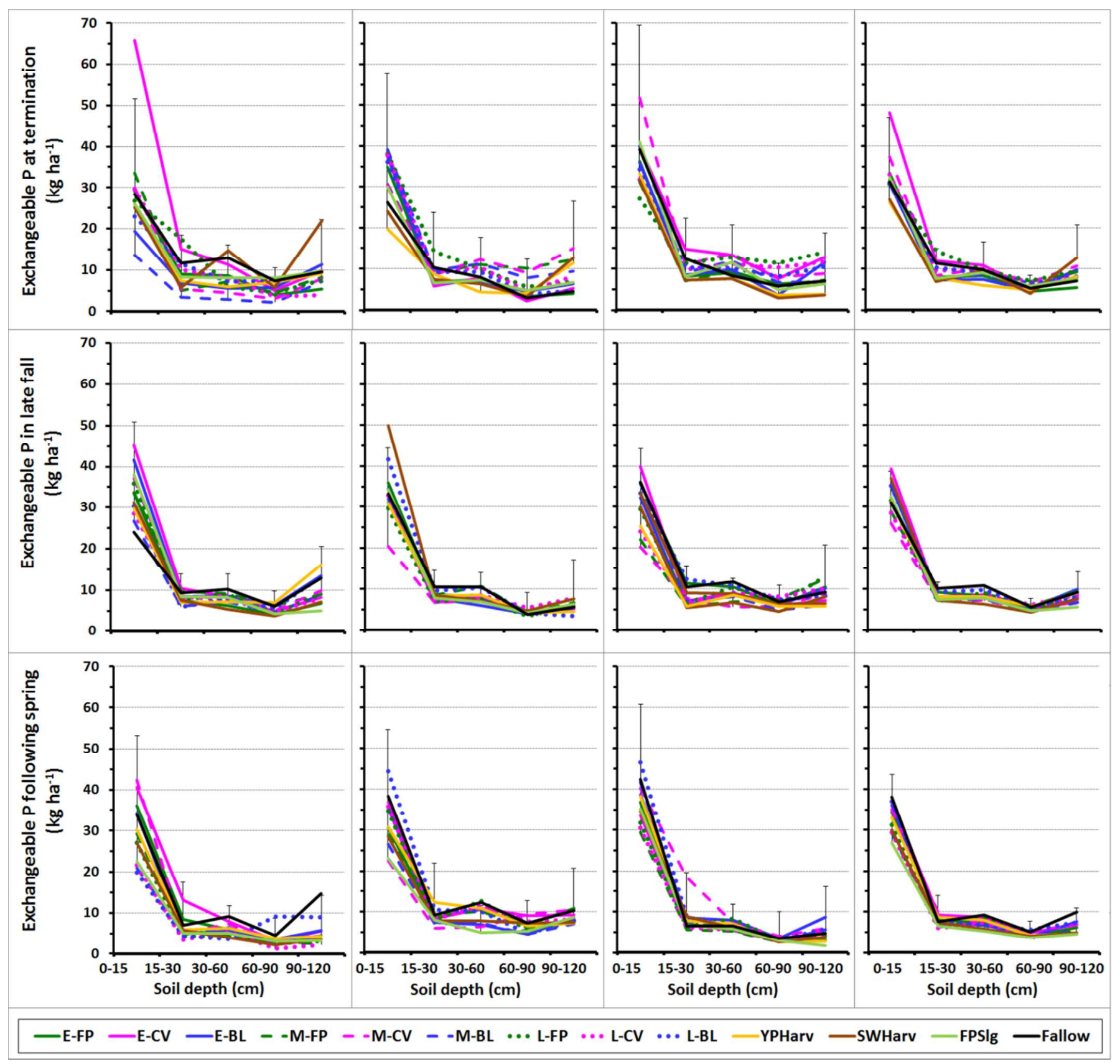

Fig. 7. Effect of different green manure crops (forage pea [FP], chickling vetch [CV], and black lentil [BL] seeded early [E], mid [M] and late [L], FP cut for silage (Slg), straw of yellow pea [YP] and spring wheat [SW] harvested (Harv) for grain, and conventional summerfallow on exchangeable $\mathrm{P}$ at termination, late fall and following spring. Error bars represent Tukey's Honestly Significant Differences (HSD) at $\alpha<0.05$ level of significance. 


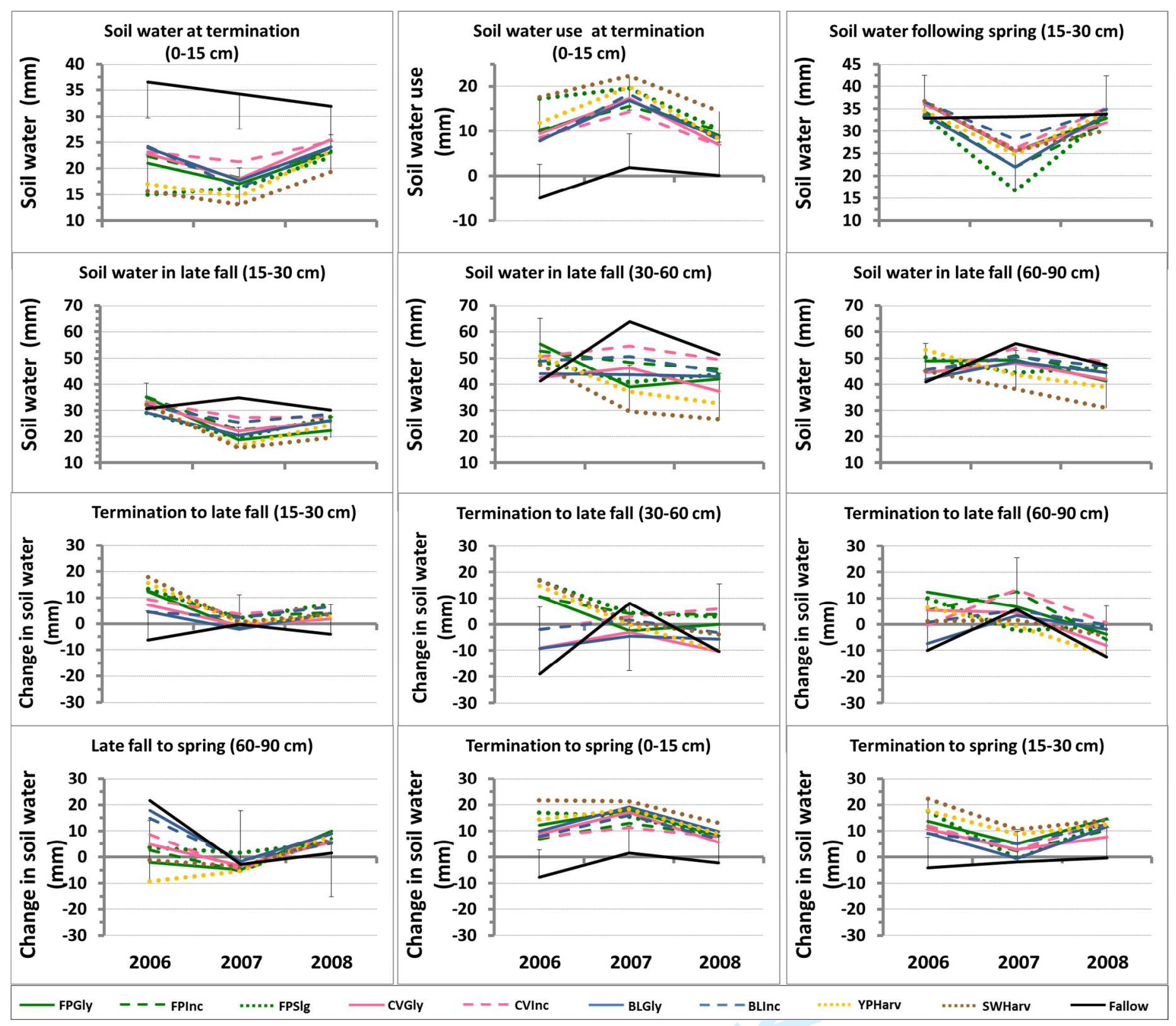

Fig. 8. Soil depths at which soil water, soil water use and changes in soil water between sampling periods exhibited year by treatment interaction effect. Error bars represent Tukey's Honestly Significant Differences (HSD) at $\alpha<0.05$ level of significance. 

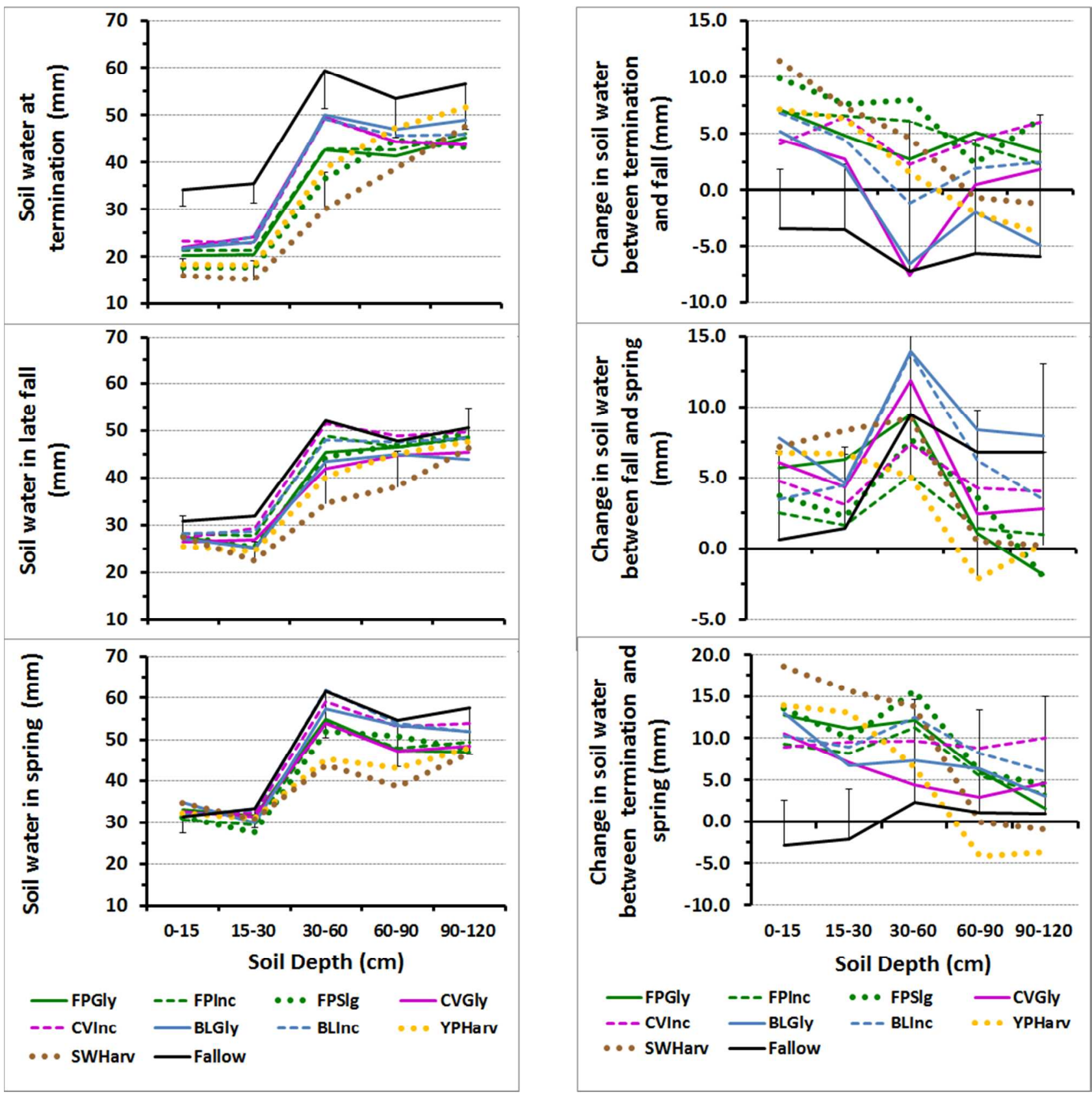

Fig. 9. Comparing effect of green manure crops (forage pea [FP], chickling vetch [CV], and black lentil [BL]) terminated by early glyphosate [Gly] or incorporation [Inc] with stubble of yellow peas [YP] and spring wheat [SW] harvested [Harv] for grain, forage peas cut for silage [Slg] and conventional fallow [Fallow] on soil water at termination, late fall, following spring and recharge between fall and spring averaged over three seasons, 2006, 2007 and 2008. Error bars represent Tukey's Honestly Significant Differences (HSD) at $\alpha<0.05$ level of significance. 


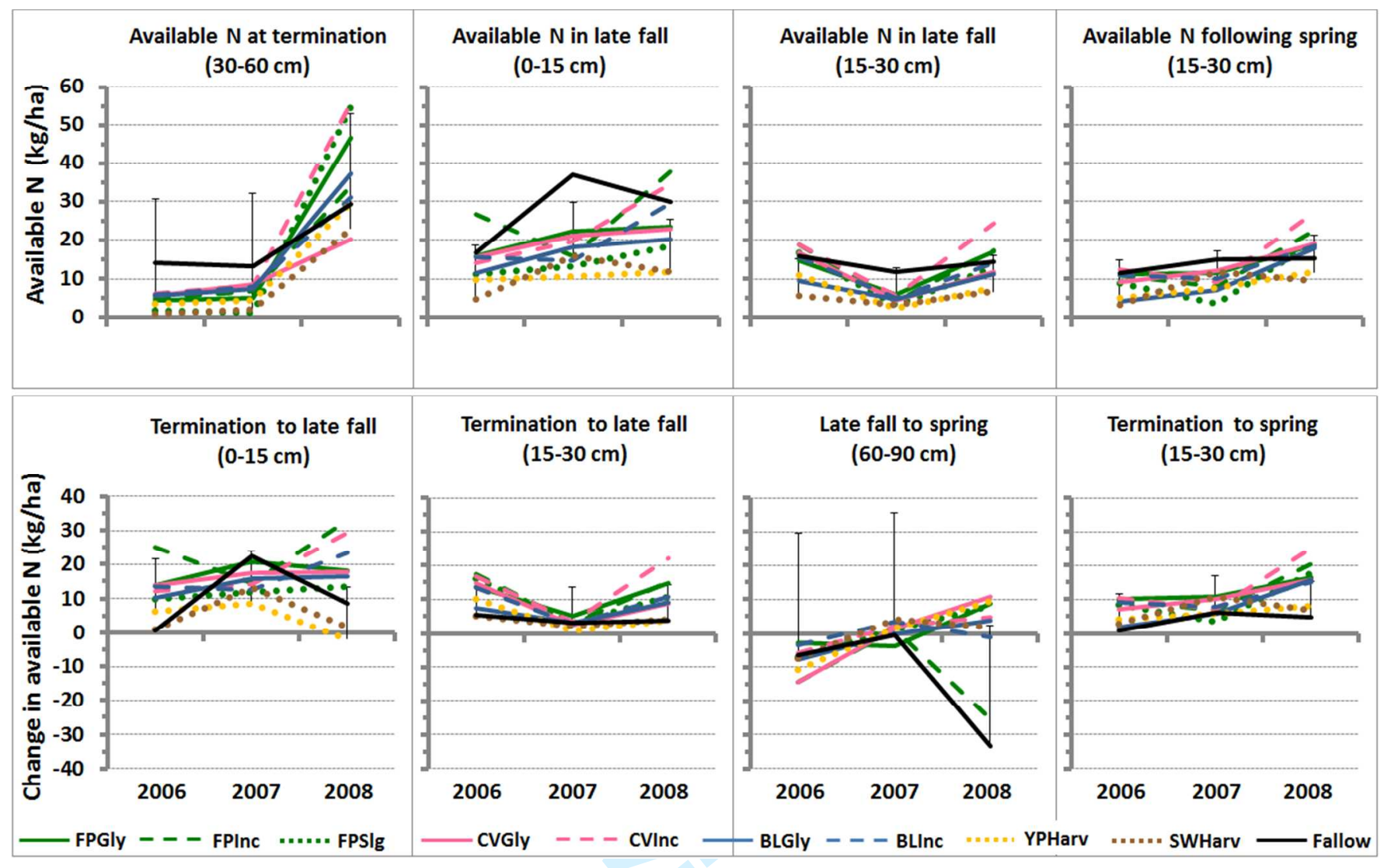

Fig. 10. Soil depths at which available nitrogen and changes in available nitrogen between sampling periods exhibited year by treatment interaction effect. Error bars represent Tukey's Honestly Significant Differences (HSD) at $\alpha<0.05$ level of significance. 

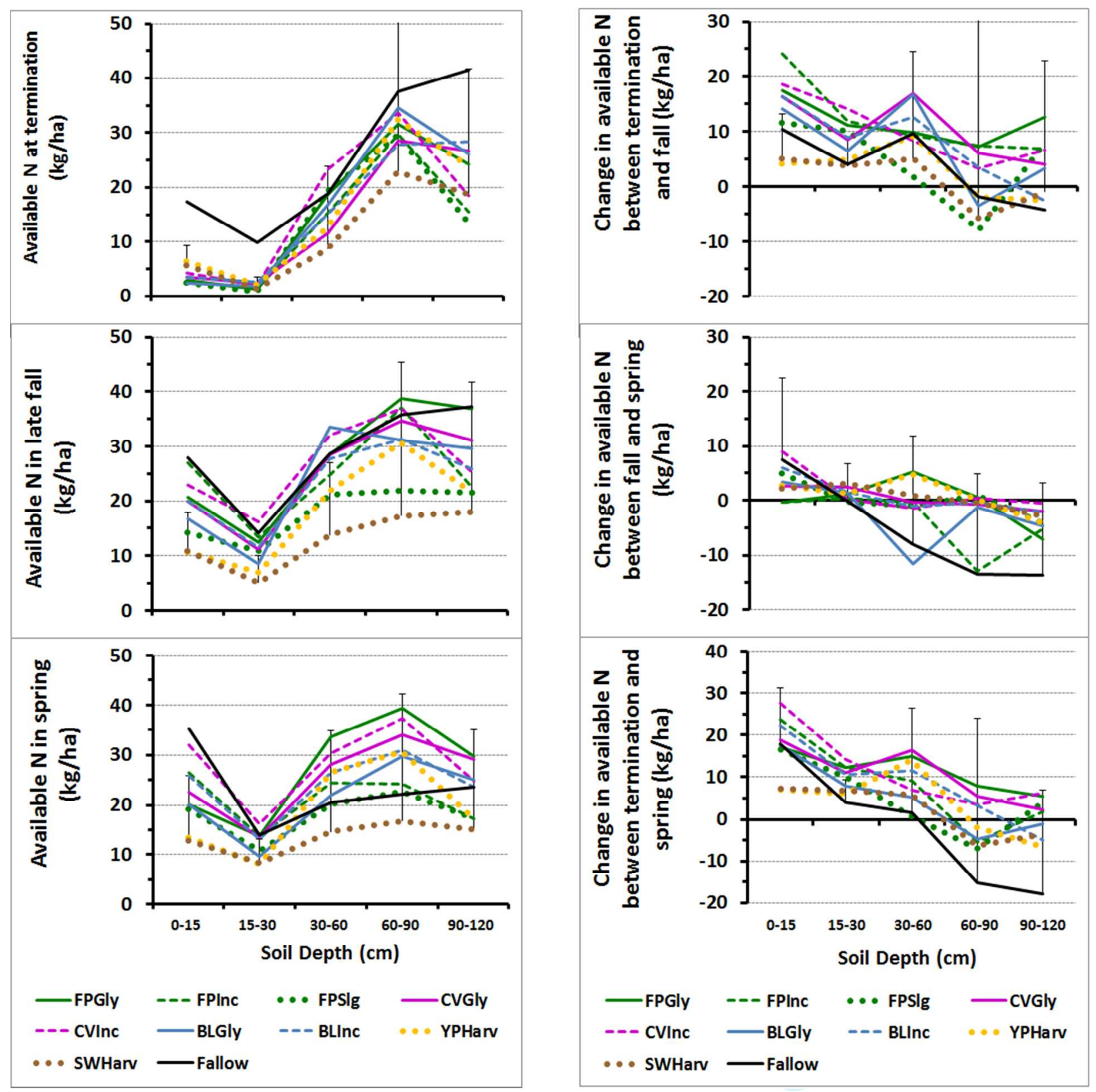

Fig. 11. Comparing effect of green manure crops (forage pea [FP], chickling vetch [CV], and black lentil [BL]) terminated by early glyphosate [Gly] or incorporation [Inc] with stubble of yellow peas [YP] and spring wheat [SW] harvested [Harv] for grain, forage peas cut for silage [Slg] and conventional fallow [Fallow] on available N averaged over three seasons, 2006, 2007 and 2008. Error bars represent Tukey's Honestly Significant Differences (HSD) at $\alpha<0.05$ level of significance. 